\title{
Commercial Lending and Distance: Evidence from Community Reinvestment Act Data
}

\author{
Kenneth P. Brevoort* \\ Timothy H. Hannan \\ Federal Reserve Board \\ Mail Stop 149 \\ Washington, DC 20551 \\ Kenneth.P.Brevoort@frb.gov \\ Timothy.H.Hannan@frb.gov
}

February, 2004

\begin{abstract}
Innovations such as credit scoring have increased the ability of banks to lend to distant business borrowers, which could expand the geographic market for small business loans. However, if this effect is limited to a few large banks, the market may become segmented and lending distance at local banks actually decrease. This paper, using a new data source and a spatial econometric model, empirically estimates the relationship between distance and commercial lending and how this relationship is evolving over time. We find distance is negatively associated with the likelihood of a local commercial loan being made and that the deterrent effect of distance is consistently more important, the smaller the size of the bank. We find no evidence that distance is becoming less important in the United States in recent years. In fact, the bulk of the evidence suggests that distance may be of increasing importance in local market lending.
\end{abstract}

\footnotetext{
${ }^{*}$ The opinions expressed in this paper are those of the authors and do not necessarily reflect the views of the Board of Governors of the Federal Reserve System or its staff. The authors would like to thank Bob Adams, Ron Borzekowski, Hendrik Hakenes, Beth Kiser, Robert Marquez, Mack Ott, Robin Prager, John Wolken, and participants of the 2003 Competition in Banking Conference at the Katholieke Universiteit Leuven in Belgium and the 2003 ASSA meetings in Washington, DC. Onka Tenkean provided outstanding research assistance and James Tedrick provided programming support. Any errors are the responsibility of the authors.
} 


\section{Introduction}

The geographic area over which banks are willing to extend credit has important implications for competition in bank lending and the application of antitrust policy. There is some evidence that improvements in information technology, most notably credit scoring, may have increased the ability of banks to lend to distant business borrowers. Such a shift could expand the size of a geographic market, but if this effect is limited to larger lenders, a possible consequence is that the market becomes segmented and that lending distance at more local banks actually decreases. This paper, using a new data source and a spatial econometric model, empirically estimates this relationship between distance and commercial lending and how this relationship is evolving over time.

A recent study by Petersen \& Rajan (2000) uses the 1993 Survey of Small Business Finance (SSBF) to examine how the distance between borrowers and bank lenders have been changing over time and reports that average distances are increasing. There is reason to believe, however, that the phenomenon of increasing distance has not been uniform. In comparing data from the 1993 and 1998 SSBFs, Wolken \& Rohde (2002) find that, while average distance between lenders and small business borrowers increased, median distances changed only minimally, suggesting that the phenomenon of increasing distance between lender and borrower may be occurring only at the extreme tail of the distribution.

Neither of these studies addresses the possibility that the technological advancements that led to these changes, most notably credit scoring, may have been adopted more fully by larger banks. Thus the increase in the average distance between borrower and lender may be the result of a small number of banks who, because of the new technology, have effectively become national or regional lenders.

Theories presented by Dell'Ariccia \& Marquez (forthcoming) and Hauswald \& Marquez (2002) suggest that greater competition by these distant lenders may cause local lenders to focus on the loans for which they have an informational advantage, and this may involve shorter, rather 
than longer, distances between these lenders and their borrowers. While a relatively uniform lowering of the costs of lending at greater distances for all banks would clearly imply a broadening of the geographic markets relevant to small business lending, a change in lending costs that applies to only a few large banking organizations could, because of these considerations, imply something quite different for antitrust market definitions and antitrust policy.

To examine whether the relationship between distance and small business lending has been increasing across the board, or whether it has evolved asymmetrically across lenders, we exclusively examine within-market lending, where we consider only loans from local banks to local businesses. This approach diminishes the effect of large banks that make loans nationwide, which may have driven the changes in average distance reported by Petersen \& Rajan (2000) and Wolken \& Rohde (2002). Instead, our paper examines whether the changes in technology have been adopted by a wide enough spectrum of banks to influence not only national lending, but local lending as well.

This paper analyzes a new source of data collected annually as a result of changes in the regulations implementing the Community Reinvestment Act (CRA), that provide detailed spatial information of the type needed to investigate within-market spatial characteristics of commercial lending. As a result of these regulatory changes, lending institutions above a modest size reported annually on the small business loans that they originate. Most importantly, the loan data is reported by geographic location of the borrower. This, combined with detailed information on the locations of the offices of lending institutions, makes it possible to calculate relevant distances between the lender and the borrower.

Specifically, in this paper we employ annual CRA data over the period 1997 - 2001 for nine different metropolitan areas in the United States to investigate the role of distance in withinmarket lending and how it has changed over time. One metropolitan statistical area (MSA) or consolidated metropolitan statistical area (CMSA) was randomly selected from the population of MSAs and CMSAs ${ }^{1}$ with populations in excess of one million for each of the nine census regions in the U.S. For each city, data were compiled for all CRA-reporting banks that had 
established branches within the boundaries of the MSAs. The data indicate the number of loan originations made by each bank to each of the census tracts within the MSA for each of the years 1997-2001.

A probit model is employed to estimate the likelihood of a bank making a loan to at least one firm in each census tract in the metropolitan area, given the identify of the bank, the number of small businesses in the census tract, and the distance between the center of the census tract and the location of the nearest branch of that bank. Because of the paucity of data available at the census tract level, we employ spatial econometric methods. Specifically, to account for unobserved variables that may be spatially correlated across census tracts, the probit is specified, as in McMillen (1992), to allow for spatially dependent errors and to correct for the resulting heteroscedasticity. The results of this estimation procedure are used to test hypotheses relating to the role of distance in commercial lending and also to examine how that role has changed over time.

Using these data, we find that, even within areas generally considered to represent a local market, distance is negatively associated with the likelihood of a commercial loan being made. Further, this deterrent effect of distance is consistently more important the smaller the size category of the bank. In other words, distance matters in explaining where a bank chooses to lend in a metropolitan area, and it matters more for smaller banks than for larger banks.

With respect to the changing importance of distance over time, the results of this study suggest that there has been no discernable increase in the distance between lenders and their local borrowers in the United States in recent years. In fact, the bulk of the evidence suggests that distance may be of increasing importance in local market lending. This finding is consistent with the theoretical predictions of both Dell'Ariccia \& Marquez (forthcoming) and Hauswald \& Marquez (2002).

The plan of the paper is as follows. Section 2 summarizes the theoretical reasons why distance may be important in lending and reviews the empirical evidence, focusing on those

\footnotetext{
${ }^{1}$ Hereafter, the term "MSA" will be used to refer to both MSAs and CMSAs.
} 
studies that have specifically addressed how the relationship between distance and lending may be changing over time. Section 3 describes the estimation procedure employed to account for spatially correlated errors. Section 4 discusses the data used and Section 5 describes the results obtained. A final section summarizes the analysis and presents conclusions.

\section{Literature}

Studies have consistently demonstrated the importance of distance in the provision of banking services. Using data from the 1993 Survey of Small Business Finance (SSBF), Kwast, Starr-McCluer \& Wolken (1997) report that 92.4 percent of small businesses use a depository institution that is within a distance of 30 miles. Furthermore, these authors find that the median distance between a small business and its lender is six miles or less for lines of credit, mortgage loans, equipment loans, motor vehicle loans, and other loans. The only traditional credit product that had a greater median distance was capital leases at 39 miles. Using more recent data

from the Credit, Banks and Small Business Survey, conducted by the National Federation of Independent Business, Scott (2003) finds that in 2001, the average distance (measured in travel time) between a small business and its primary financial institution was 9.5 minutes, with a median of 5 minutes.

The theoretical literature has put forth two different rationales for why distance should serve as a deterrent to lending. The first, drawn from traditional models of spatial competition, is borrower travel cost. Prospective borrowers must incur travel costs to do business with a lender, in much the same way that is more commonly asserted for a depositor that chooses to do business with one depository institution rather than another. Papers by Chiappori, Perez-Castrillo \& Verdier (1995) and Park \& Pennacchi (2003) are examples of this type of rationale.

The second rationale, more specific to the case of commercial credit, concerns the advantage that proximity may give lenders in screening perspective borrowers and monitoring loans, particularly in the case of loans to small businesses. Lenders, lacking the "hard" information 
provided by detailed public financial statements typically available for large firms, have to rely on "soft" information informally collected through relationships between the lender and the borrower. $^{2}$ The collection of this soft information is costly to the lender, as it may require multiple site visits by a loan officer to the small business or specialized knowledge of the local market in which the firm operates. Additionally, banks may acquire information on small firms through the provision of non-loan-related banking services, such as checking accounts that are most often provided by local suppliers. In these instances, a firm would be more likely to receive favorable loan terms from lenders in closer proximity to the firm, as close lenders would incur lower costs to gather soft information. ${ }^{3}$ Almazan (2002) provides an example of this type of model.

Most directly applicable to the issues relating to how changes in the competitive environment might alter the relationship between distance and lending are the theoretical models of Dell'Ariccia \& Marquez (forthcoming) and Hauswald \& Marquez (2002). If large banks have access to a cheaper source of funds (Kiser forthcoming), this may allow these banks to extend loans to more distant markets, even though the large banks might be at an informational disadvantage relative to closer, local financial institutions. Dell'Ariccia \& Marquez (forthcoming) provide a model of this type of situation and examine how the extension of credit in local markets might be affected by changes in either the cost advantages of the less-informed banks or in the degree of informational asymmetry among financial institutions. The authors show that greater competition from outside lenders will cause local banks to reallocate credit towards borrowers for whom the local lenders possess an informational advantage (an effect that Dell'Ariccia and Marquez term a "flight to captivity"). If proximity confers an informational advantage, this suggests that greater competition from outside lenders might result in local lenders reducing the distance over which they extend credit to businesses.

In a related paper, Hauswald \& Marquez (2002) present a model that focuses on "informa-

\footnotetext{
${ }^{2}$ For a review of issues involved in small business lending, see Berger \& Udell (1998).

${ }^{3}$ The importance of relationships in small business lending has received increasing attention in the academic literature in recent years. For a review of relationship banking see Boot (2000).
} 
tional distance" and its relationship to investments in information acquisition technology by lenders. An implication of their model is that, as competition increases, banks may respond by shifting their resources to loans involving greater informational proximity. If informational proximity translates to physical proximity, then a reduction in the distance between borrower and lender as competition increases is a possible outcome.

Together, the papers by Dell'Ariccia \& Marquez (forthcoming) and Hauswald \& Marquez (2002) suggest that the competitive changes brought about by technological changes in bank lending may have asymmetric effects on the relationship between distance and lending. In particular, while technological changes may lead some financial institutions to lend beyond their local markets, the resulting changes in the competitive environment might lead local lenders to restrict their lending activities to a smaller geographic area.

While these theoretical studies have established why distance would be important and how changes in the competitive environment might alter the importance of distance, very few studies have empirically examined the evolving relationship between distance and bank lending. One study by Petersen \& Rajan (2002) examines how the relationship between distance and lending is changing over time. Using the $1993 \mathrm{SSBF}$, the authors conclude that the distance between small firms and their lenders is increasing over time and that this phenomenon is correlated with improvements in bank productivity. These findings were based on the "synthetic panel" that the authors constructed from the 1993 SSBF cross section, wherein the distance between borrower and lender is compared with the time at which respondents in the $1993 \mathrm{SSBF}$ report the lending relationship began.

A more direct comparison over time that examines more recent years was conducted by Wolken \& Rohde (2002), who compare results of the 1993 and 1998 SSBF surveys. They find that for small business loans in general, the average distance between the business's headquarters and the financial institution making the loan increased from 115 miles in 1993 to 244 miles in 1998, while the median distance increased from only 9 to 10 miles during the same period. It is clear that this sharp distinction between the mean and median changes is driven by a sharp 
increase in distance exhibited at the upper tail of the distribution. Decomposition according to type of loan reveals that this phenomenon has been particularly pronounced for capital leases and motor vehicle loans. ${ }^{4}$

A third study that addressed the relationship between distance and lending over time was conducted by Degryse \& Ongena (2002). In a paper that examines how the distance between a borrower and a lender affects the interest rate paid on loans from a large Belgian bank, the authors address the issue of whether the distances between borrowers and the bank have been changing over time. They conclude that the distance between the bank in their study and the European firms it served did not increase substantially between 1975 and 1997.

Taken together, the results of the first two empirical studies are consistent with the notion that there has been an increase over time in the distance between lender and borrower for "intermarket" loans, or loans made over longer distances. While this increase in distance may be the result of innovations in broad-based screening techniques, they provide little evidence of a trend in distances for more local, "relationship-driven" loans. Similarly, the results of Degryse and Ongena (2002) suggest that the trend in the importance of distance may not be occurring for all banks.

While it is possible that the innovations that have resulted in the rise of longer-distance "intermarket" loans may be at work to increase distances associated with shorter-distance, "intramarket" loans, this need not be the case. Indeed, the results of the existing empirical literature are not inconsistent with the predictions of Dell'Ariccia \& Marquez (forthcoming) and Hauswald \& Marquez (2002) relating to the asymmetric effects on the relationship between distance and lending.

\footnotetext{
${ }^{4}$ Using the distinction made by Berger \& Udell (1995), capital leases and motor vehicle loans are "transactiondriven" as opposed to "relationship-driven," which may partially explain why changes in the markets for those loan products differed from other types of small business lending.
} 


\section{$3 \quad$ The Empirical Model}

This paper employs a probit model that allows for spatially-dependent errors and corrects for heteroscedasticity. The probability that a bank extends credit to a census tract is a function of the attractiveness of the commercial credit market conditions in that census tract. Attractiveness can affected by the demand characteristics of potential borrowers in that census tract, the ability of banks to reach potential borrowers in that census tract, the degree of adverse selection the bank faces, or other considerations. A bank, $b$, makes a loan to census tract $c$ in year $t$ if the latent variable $L_{b c t}$, which represents the attractiveness of the lending environment of the census tract to bank $b$, is greater than zero. This latent variable is assumed to follow a linear functional form given by

$$
L_{b c t}=X_{b c t} \beta+u_{b c t}
$$

where $u_{b c t}$ is a random normal disturbance term, $\beta$ is a $k x 1$ vector of coefficients, and $X_{b c t}$ is a $1 x k$ vector of explanatory variables reflecting the characteristics of the bank making the loan, the census tract into which the loans are made, and the interaction between the bank and census tract (such as the distance between the bank and the census tract).

The random disturbance terms are assumed to have a spatial autoregressive structure, so that $u_{b c t}=\rho \sum_{j} w_{c j} u_{b j t}+\epsilon_{b c t}$, where $\rho$ is a parameter indicating the strength of the spatially autoregressive process, $w_{c j}$ is a measure of spatial contiguity, and $\epsilon_{b c t}$ is an i.i.d. draw from a standard normal distribution. The parameter $\rho$ therefore reflects the influence of unobserved characteristics of neighboring census tracts that are correlated across space, rather than the impact of observations across time.

Written in matrix notation, the model specification can be expressed as 


$$
\mathbf{L}=\mathbf{X} \beta+(\mathbf{I}-\rho \mathbf{W})^{-1} \epsilon
$$

and

$$
E \mathbf{u u}^{\prime}=\left[(\mathbf{I}-\rho \mathbf{W})^{\prime}(\mathbf{I}-\rho \mathbf{W})\right]^{-1}
$$

$W$ is the spatial weight matrix that describes the spatial pattern of the autoregressive process. In this application $w_{c j}$ is equal to the proportion of census tract $c^{\prime} s$ border that is shared with census tract $j$. If census tracts $c$ and $j$ are nonadjacent, then $w_{c j}$ is equal to zero. Following convention in the spatial econometrics literature, $w_{c c}$ is equal to zero. ${ }^{5}$

The complex error structure in this model makes the use of direct maximum likelihood methods infeasible, so we employ the expectation-maximization (EM) algorithm, an iterative method of estimating $\beta$ and $\rho .{ }^{6}$ First, we begin with starting values of $\hat{\beta}$ and $\hat{\rho}$. Using these values, the expected value of the latent variable $\hat{L_{b c t}}$ is calculated, conditional on whether bank $b$ actually was observed making a loan to census tract $c$ in year $t$. New values of $\hat{\beta}$ and $\hat{\rho}$ are then selected to maximize the likelihood function derived by McMillen (1992),

$$
\max _{\beta, \rho}=-0.5\left(L_{b c t}-X \beta\right)^{\prime}(I-\rho W)^{\prime}(I-\rho W)\left(L_{b c t}-X \beta\right)+\sum_{i} \ln \left(1-\rho \omega_{i}\right),
$$

where $\omega_{i}$ is the $i$-th eigenvalue of the spatial weight matrix. These values of $\hat{\beta}$ and $\hat{\rho}$ are then used to update the expected value of the latent variable $\hat{L_{b c t}}$. The EM algorithm continues this process until the change in the values of $\hat{\beta}$ and $\hat{\rho}$ fall below a specified tolerance. ${ }^{7}$

\footnotetext{
${ }^{5}$ For a review of the use of spatial weight matrices in spatial econometrics, see Anselin (1998) or LeSage (1998).

${ }^{6}$ Amemiya (1985) provides an overview of the application of the EM algorithm to discrete choice models.

${ }^{7}$ The tolerance used in the estimations reported in this paper was $10^{-8}$.
} 


\section{Data}

The data on small business lending patterns are collected by the Federal Reserve Board to satisfy the Community Reinvestment Act (CRA). Under this act, independent lending institutions with total assets greater than $\$ 250$ million, or institutions of any size if they are owned by a holding company with more than $\$ 1$ billion in total assets, must report annually on the small business loans that they originate or hold. Both the number and volume of loans are recorded for each reporting bank for the census tract to which the loans were made.

Due to the large number of census tracts in the United States and the computational complexity involved in estimating a spatial probit model, a study that encompasses the entire United States is not feasible. As a result, this study focuses on lending patterns in nine cities located throughout the U.S. ${ }^{8}$ These cities were selected at random from the universe of MSAs and CMSAs with populations over 1 million. One city was selected from each of the nine census regions to make the sample geographically diverse. The MSAs selected include the cities of Atlanta, GA; Denver, CO; Indianapolis, IN; Kansas City, MO; Nashville, TN; Providence, RI; Rochester, NY; San Antonio, TX; and Seattle, WA. The complete names and code numbers of each of these MSAs are provided in Table 1. CRA data were compiled for each of these MSAs.

Each of the CRA-reporting banks in each of the nine cities was checked against the FDIC's Institution Directory to determine if that bank had established at least one office within the MSA. For those banks with offices in the MSA, a list of addresses of each bank's branches in that MSA was compiled for each year. These addresses were then geocoded to the longitude and latitude coordinates of the branch address. Banks that were making loans within the MSA, but that did not have a local branch presence ("out of market lenders"), were excluded from the sample to focus exclusively on local market lending.

\footnotetext{
${ }^{8}$ Over the years, the academic literature has provided substantial support for the existence of geographically limited markets for both retail deposits and small business loans. The bulk of the evidence has come in the form of price-concentration studies, wherein bank deposit rates or bank loan rates are regressed on measures of local market concentration, calculated under the assumption that MSAs and non-MSA counties approximate local banking markets. See, for example, Berger \& Hannan (1989), Calem \& Carlino (1991), and Hannan (1991).
} 


\begin{tabular}{ll}
\hline \hline FIPS Code & Name \\
\hline 0520 & Atlanta, GA MSA \\
2082 & Denver-Boulder-Greeley, CO CMSA \\
3480 & Indianapolis, IN MSA \\
3760 & Kansas City, MO-KS MSA \\
5360 & Nashville, TN MSA \\
6480 & Providence-Fall River-Warwick, RI-MA MSA \\
6840 & Rochester, NY MSA \\
7240 & San Antonio, TX MSA \\
7602 & Seattle-Tacoma-Bremerton, WA CMSA \\
\hline \hline
\end{tabular}

Table 1: Metropolitan Statistical Areas Used in this Study

Among loans made by CRA-reporting institutions, the share of loans made by within market lenders has fallen substantially over the time frame of this study. ${ }^{9}$ This decline, which is shown in Table 2, is demonstrative of the growing importance of out-of-market lenders. While the market share of the within market lenders has fallen in terms of number of loans made each year, market share in terms of loan volume (shown in Table 3) has been much more stable. In 2001, the most recent year of data, the within-market lenders examined in this study accounted for at least 80 percent of dollar volume of loans reported by CRA-reporting banks in each of the nine MSAs examined.

For each MSA, the model was estimated using a panel data set consisting of census tract observations over the years 1997 to 2001. For each of the within market lenders, the log of the great circle distance (or "distance as the crow flies") between the centroid of each census tract and the closest branch of the bank in that MSA was calculated. Since this study is primarily interested in how the importance of distance is changing over time, the log of distance is also interacted with a linear time trend. To allow for the possibility that distance may differ in importance to banks of different sizes, both of these variables are interacted with dummy variables for medium (assets between $\$ 500$ million and $\$ 5$ billion) and large size banks (assets

\footnotetext{
${ }^{9}$ The small business loans reported by financial institutions under CRA requirements include loans made through credit cards, and such loans tend to involve substantial distances between lender and borrower. Also, the loans of institutions not large enough to come under CRA reporting requirements tend to be more local. For both of these reasons, the share of CRA-reported loans made by within-market institutions will underestimate the true share of within-market non-credit card loans. Nonetheless, it is instructive to examine these observed shares.
} 


\begin{tabular}{lccccc}
\hline \hline Variable & 1997 & 1998 & 1999 & 2000 & 2001 \\
\hline Atlanta & 47.1 & 53.6 & 46.9 & 25.0 & 25.1 \\
Denver & 50.7 & 56.4 & 54.9 & 30.2 & 29.0 \\
Indianapolis & 57.4 & 52.9 & 53.4 & 32.1 & 28.9 \\
Kansas City & 53.1 & 51.4 & 44.8 & 29.3 & 29.7 \\
Nashville & 67.0 & 61.3 & 61.8 & 36.4 & 40.0 \\
Providence & 43.1 & 46.8 & 36.8 & 18.6 & 24.7 \\
Rochester & 70.0 & 66.0 & 61.5 & 42.8 & 43.4 \\
San Antonio & 62.6 & 55.0 & 40.4 & 23.1 & 22.7 \\
Seattle & 71.0 & 65.7 & 56.6 & 33.7 & 25.9 \\
\hline \hline
\end{tabular}

Table 2: Market Share of Loans Made by CRA-Reporting Institutions Operating within the MSA

\begin{tabular}{lccccc}
\hline \hline Variable & 1997 & 1998 & 1999 & 2000 & 2001 \\
\hline Atlanta & 83.5 & 88.8 & 86.2 & 80.7 & 83.9 \\
Denver & 82.7 & 85.3 & 85.8 & 79.4 & 81.4 \\
Indianapolis & 89.4 & 88.7 & 88.6 & 84.6 & 80.2 \\
Kansas City & 88.2 & 90.5 & 86.1 & 82.7 & 85.5 \\
Nashville & 90.6 & 91.9 & 90.0 & 86.0 & 87.6 \\
Providence & 84.0 & 85.3 & 81.6 & 70.2 & 80.8 \\
Rochester & 94.5 & 92.2 & 92.1 & 89.0 & 90.5 \\
San Antonio & 88.0 & 85.9 & 84.8 & 76.6 & 82.6 \\
Seattle & 95.1 & 93.3 & 91.0 & 84.1 & 85.5 \\
\hline \hline
\end{tabular}

Table 3: Market Share of Loan Volume by CRA-Reporting Institutions Operating within the MSA

over $\$ 5$ billion). Also, to account for bank-specific heterogeneity, bank-specific fixed effects are employed in each of the estimations performed.

Factors other than distance and bank characteristics - for example, the characteristics of potential borrowers in the census tract - are important in bank lending decisions. A considerable problem encountered in conducting analyses of bank lending at the a census-tract level is the lack of available data at that level. One source is Dunn \& Bradstreet, which compiles data on the number of businesses located in each census tract in the United States over the time period of this study. The log of the number of firms is included as an indication of the strength of demand for loans in each census tract. In addition, to account for additional unobserved heterogeneity across census tracts, census-tract-specific fixed effects are employed in some of the model specifications. 


\begin{tabular}{|c|c|c|c|c|c|c|c|c|c|}
\hline$\overline{\overline{\text { Variable }}}$ & 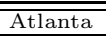 & 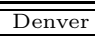 & Indianapolis & Kansas City & $\overline{\text { Nashville }}$ & Providence & קRochester & San Antonio & $\overline{\overline{\text { Seattle }}}$ \\
\hline Tracts & 495 & 507 & 331 & 443 & 204 & 335 & 260 & 255 & 613 \\
\hline Observations & 73,260 & 107,991 & 35,086 & 62,020 & 14,892 & 29,815 & 18,980 & 24,480 & 77,238 \\
\hline Banks & 45 & 58 & 32 & 41 & 24 & 22 & 20 & 34 & 38 \\
\hline Bank-years & 148 & 213 & 106 & 140 & 73 & 89 & 73 & 96 & 126 \\
\hline Small & 68 & 140 & 28 & 66 & 12 & 21 & 21 & 14 & 45 \\
\hline Medium & 42 & 44 & 45 & 50 & 15 & 48 & 17 & 37 & 48 \\
\hline Large & 38 & 29 & 33 & 25 & 46 & 20 & 35 & 45 & 33 \\
\hline Mean Bank Assets & 26.680 & 4.4541 & 9.1747 & 3.5048 & 52.249 & 9.6832 & 39.1395 & 52.9236 & 22.7584 \\
\hline Std. Dev. Bank Assets & 66.425 & 14.065 & 15.844 & 11.750 & 110.11 & 28.227 & 60.3034 & 109.121 & 79.5468 \\
\hline Mean Distance & 20.764 & 11.805 & 10.846 & 13.096 & 9.6631 & 10.624 & 14.1808 & 9.6763 & 17.8570 \\
\hline Std. Dev. Distance & 16.874 & 11.869 & 9.7368 & 11.781 & 9.6803 & 9.0375 & 14.0914 & 9.9317 & 17.2731 \\
\hline Mean Firm Count & 351.0 & 235.9 & 175.24 & 158.99 & 263.126 & 180.38 & 179.064 & 215.863 & 296.0536 \\
\hline Std. Dev. Firms & 322.4 & 236.5 & 176.89 & 144.81 & 234.742 & 135.19 & 143.148 & 209.019 & 266.1723 \\
\hline
\end{tabular}

Notes: Means and standard deviations for assets, distance, and firm counts are for 2001. Assets are measured in billions of dollars.

Table 4: Summary Statistics 
Summary statistics for the data set employed in this paper are provided in Table 4 . The summary statistics show a substantial amount of heterogeneity across MSAs. In terms of the number of census tracts, the size of the MSAs range from Nashville with 204 tracts to Denver which has almost twice as many. Even greater disparities are seen in cross-MSA comparisons of the remaining variables. The distribution of observations across bank size categories also is substantially different across the MSAs examined. These statistics suggest that the MSAs selected for use in this study represent a broad cross section of large MSAs.

\section{$5 \quad$ Results}

Table 5 lists and defines all variables used in the estimations reported in the succeeding tables. ${ }^{10}$ Complete estimation results are presented in Tables 12 through 20 in the appendix. Each table presented in the text provides a summary of the results across different specifications for those coefficients of particular interest.

\begin{tabular}{ll}
\hline \hline Variable & Description \\
\hline D1998-D2001 & Year dummy variables \\
$\mathrm{S}$ & Small firm dummy (assets $<\$ 500$ million) \\
$\mathrm{M}$ & Medium firm dummy $(\$ 500$ million $<$ assets $<\$ 5$ billion) \\
$\mathrm{L}$ & Large firm dummy (assets $>\$ 5$ billion) \\
$\mathrm{LnD}$ & Log of distance between census tract and nearest bank branch (in miles) \\
$\mathrm{T}$ & Linear time trend $(1997=0)$ \\
LnFirms & Log of firm count in census tract \\
\hline \hline
\end{tabular}

\section{Table 5: Variable List}

Multiple model specifications were estimated for each of the nine MSAs. Each estimation includes bank-specific fixed effects, year dummies $(D 1998$ - D2001), the log of one plus the number of small firms in each census tract as reported by Dunn \& Bradstreet $(\text { LnFirms })^{11}$, and the $\log$ of the distance from the centroid of each census tract to the nearest branch of the

\footnotetext{
${ }^{10}$ The dummy variables used for bank-level and census-tract-level fixed effects are not listed in the tables nor reported in with the results to conserve space.'
} 
bank $(L n D)$.

Two alternative specifications were estimated to allow for the possibility that the importance of distance may be changing over time. In specification I, $\operatorname{LnD}$ is interacted with a linear time trend that is constant across banks. The second specification allows for the possibility that the changing importance of distance might differ across size category of financial institution by interacting $\operatorname{LnD}$ with separate linear time trends for small, medium, and large financial institutions.

To account for the possibility of unobserved heterogeneity across census tracts each of these two specifications was also estimated with and without time-invariant, census-tract fixed effects (TFE). In addition, to test the sensitivity of the model to the assumption of spatially-correlated errors, we also estimate probit models where the residuals are assumed to be independently distributed. The results of both the spatial and aspatial probits are qualitatively similar. While the discussion in the following sections focuses exclusively on the results from the spatial probit, the coefficients from both models are presented in the Appendix.

\subsection{Specification I: Single Linear Time-Distance Trend}

The estimations that included a single linear time trend on the impact of distance across size class of financial institution provide consistent results regarding the determinants of bank lending to census tracts. Table 6 provides a summary of the coefficients on LnFirms for the specification that includes a single linear time-distance trend for the cases in which tract fixed effects are included ("TFE") and not included ("No TFE").

For the estimations that do not include tract fixed effects, the coefficient on LnFirms is uniformly positive and highly significant in each of the nine MSAs. When census tract fixed effects are included, in which case identification of the effect of LnFirms comes from variations

\footnotetext{
${ }^{11}$ Additional estimations that decompose the number of businesses into their one-digit SIC classifications were also performed. The results from these estimations are similar to the results reported here, though the collinearity among the SIC variables was such that many of the SIC coefficients had negative or inconsistent signs. The coefficients on the other variables were largely unaffected. To save space, these specifications are not reported in the paper, though they are available from the authors upon request.
} 


\begin{tabular}{lcc}
\hline \hline MSA & No TFE & TFE \\
\hline Atlanta & 0.6527 & 0.1020 \\
& $(74.9016)$ & $(2.4671)$ \\
Denver & 0.7922 & 0.1925 \\
& $(88.2126)$ & $(5.1061)$ \\
Indianapolis & 0.5567 & 0.1288 \\
& $(53.7225)$ & $(3.1433)$ \\
Kansas City & 0.6056 & 0.0275 \\
& $(69.7249)$ & $(0.7799)$ \\
Nashville & 0.4805 & 0.0252 \\
& $(24.9078)$ & $(0.3286)$ \\
Providence & 0.4906 & 0.0767 \\
& $(42.5173)$ & $(1.3793)$ \\
Rochester & 0.7668 & -0.0722 \\
& $(46.6951)$ & $(-0.8234)$ \\
San Antonio & 0.6093 & -0.0063 \\
& $(46.4820)$ & $(-0.1258)$ \\
Seattle & 0.5279 & 0.0490 \\
& $(65.7587)$ & $(1.4696)$ \\
\hline \hline
\end{tabular}

Notes: TFE denotes the coefficients are from estimations that employed census tract fixed effects. T-statistics are in parentheses. As with McMillen (1992), the standard errors used to calculate the t-statistics in the estimations with spatially-dependent errors are conditional on $\rho$ and so that the t-statistics overestimate the unconditional t-statistics.

Table 6: Coefficients on Log Number of Firms in Estimations with Spatially-Correlated Errors and a Single Time-Distance Trend

in the number of firms over time, the effect is not as strong and statistically significant at the 1 percent level for only Atlanta, Denver, and Indianapolis. The results suggest, not surprisingly, that as the number of small businesses in a census tract increases, the probability of each bank extending credit to firms in that tract increases.

The coefficients on the log of distance are presented in Table 7. Like the coefficients on the number of firms, these coefficients also tell a consistent story across the different specifications and MSAs. The coefficient on the baseline distance measure, $\operatorname{LnD}$, is negative and highly significant in every case, implying that the greater the distance between a census tract and a bank's nearest branch, the less likely the bank will have extended a loan to a firm in that census tract. 


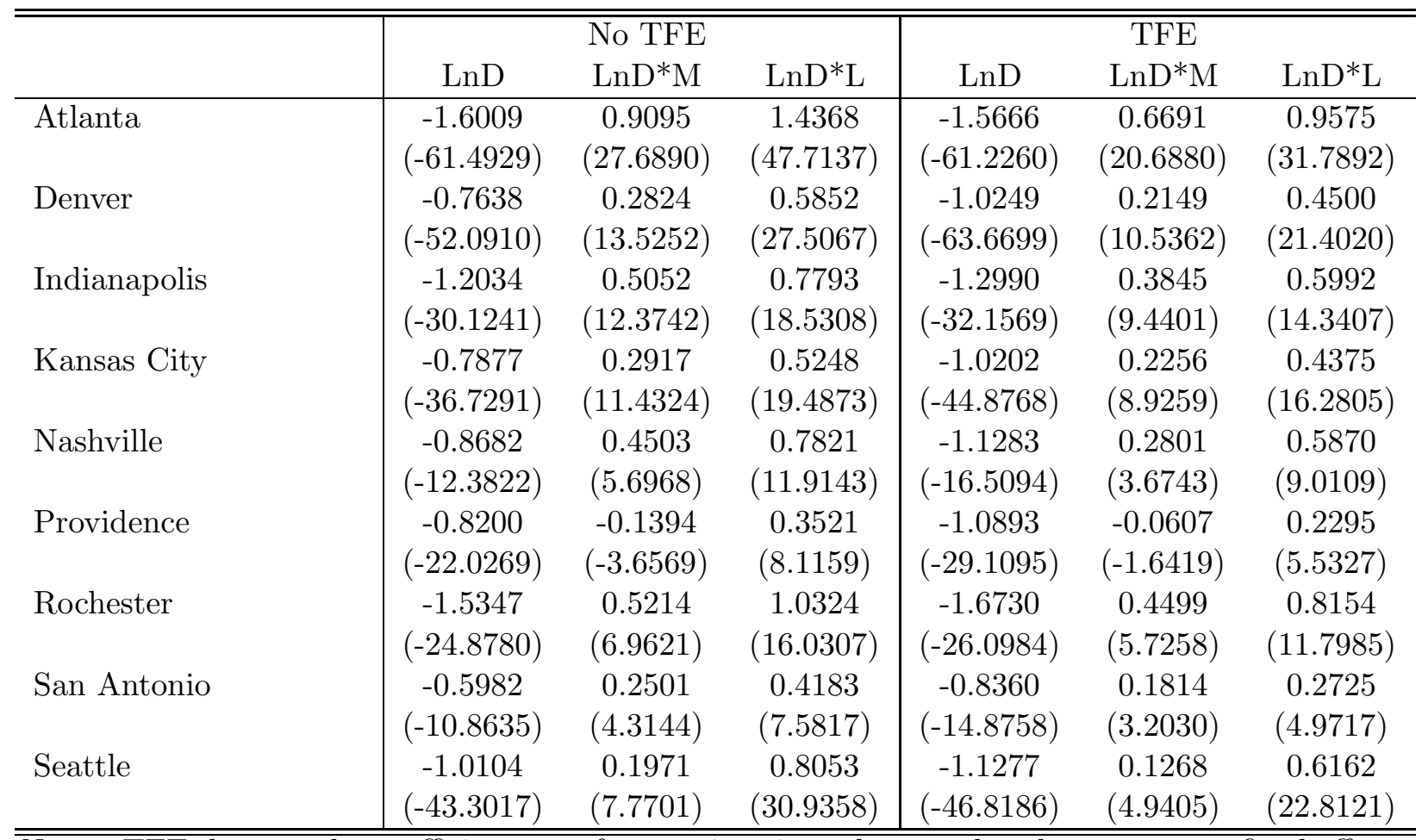

Notes: TFE denotes the coefficients are from estimations that employed census tract fixed effects. T-statistics are in parentheses. As with McMillen (1992), the standard errors used to calculate the t-statistics in the estimations with spatially-dependent errors are conditional on $\rho$ and so that the t-statistics overestimate the unconditional t-statistics.

Table 7: Coefficients on Log Distance in Estimations with Spatially-Correlated Errors and a Single Time-Distance Trend

For eight of the nine MSAs, distance was less of a deterrent at medium-sized financial institutions than at small institutions, a difference that was statistically significant at the 99 percent level in each case. In the remaining MSA, Providence, distance was more of a deterrent at medium-sized institutions than at small institutions, though this difference was only significant in the estimation without tract fixed effects. At larger institutions, the deterrent effect of distance was lower than at either small or medium institutions across all nine MSAs for both the estimations with and without tract fixed effects.

With a single linear time-distance trend across bank size categories, the deterrent effect of distance in bank lending does not appear to be diminishing over time. The coefficients for the estimations involving spatially-correlated errors are summarized in Table 8. The results presented in that table indicate that, if anything, the importance of proximity has been growing 
over time, though these results are not as clear as those for the number of firms or distance. The time-distance coefficient (the coefficient on the interaction of $T$ and $L n D$ ) is negative and significant at the 1 percent level for three cities (Atlanta, Nashville, and Providence), positive and significant for Indianapolis, and otherwise either insignificant or negative and significant only in the estimations without tract fixed effects.

\begin{tabular}{lcc}
\hline \hline MSA & No TFE & TFE \\
\hline Atlanta & -0.0477 & -0.0551 \\
& $(-8.5391)$ & $(-10.1045)$ \\
Denver & 0.0006 & 0.0026 \\
& $(0.1353)$ & $(0.5764)$ \\
Indianapolis & 0.0436 & 0.0550 \\
& $(5.5568)$ & $(7.0598)$ \\
Kansas City & -0.0174 & 0.0022 \\
& $(-2.8543)$ & $(0.3645)$ \\
Nashville & -0.0628 & -0.0418 \\
& $(-4.3098)$ & $(-2.9410)$ \\
Providence & -0.0359 & -0.0388 \\
& $(-4.3087)$ & $(-4.7124)$ \\
Rochester & -0.0129 & -0.0008 \\
& $(-1.2393)$ & $(-0.0778)$ \\
San Antonio & -0.0260 & 0.0156 \\
& $(-2.5378)$ & $(1.5164)$ \\
Seattle & -0.0086 & 0.0012 \\
& $(-1.5666)$ & $(0.2162)$ \\
\hline \hline
\end{tabular}

Notes: TFE denotes the coefficients are from estimations that employed census tract fixed effects. T-statistics are in parentheses. As with McMillen (1992), the standard errors used to calculate the t-statistics in the estimations with spatially-dependent errors are conditional on $\rho$ and so that the t-statistics overestimate the unconditional t-statistics.

Table 8: Coefficients on Time*Distance in Estimations with Spatially-Correlated Errors and a Single Time-Distance Trend

While the results discussed above indicate the direction of the effects and trends examined, they provide little information about the degree to which these trends and effects are of economic importance. To determine the economic importance of distance and how rapidly its importance is changing, if at all, over time, marginal effects were calculated for distance and time. These marginal effects indicate the change in the probability of one or more loans being extended to a 
census tract that would result from a one mile increase in distance or from a one year increase in time.

These marginal effects are calculated for 2001 using the average values presented in the summary data (Table 4) as values for the explanatory variables. Furthermore, when calculating the probabilities used in calculating the marginal effects, we assume that the spillover effects from neighboring census tracts balance out, so that $\rho \sum_{j} w_{c j} u_{b j t}=0$. All fixed effects are assumed to take on their average values across financial institutions and census tracts.

For estimations that include a single linear time-distance term, distance has a substantial impact on the probability that a financial institution extends credit to a census tract. The median marginal effects (across model specifications and MSAs) of distance are larger at smaller institutions than at larger institutions. Specifically, a one-mile increase in distance is associated with a 1.75 percentage point decrease in the probability of credit being extended to a census tract at small institutions, compared to decreases of 1.4 and 0.8 percentage points at medium and large institutions, respectively. ${ }^{12}$

While the coefficients on the time-distance trend variable provided a somewhat inconsistent indication of how distance is changing over time, the marginal effects provide a clearer view. While individual marginal effects move in either direction, the median marginal effect of time is a decrease across each of the three institution size classes. A one-year increase corresponds to a decrease in the probability of a financial institution extending credit to a census tract of 0.12 percentage points at small institutions, 0.14 at medium institutions, and 0.07 at large institutions. While these results suggest that distance is becoming more of a deterrent to local bank lending, the magnitude of the increase in the deterrent is very small.

\footnotetext{
${ }^{12}$ To reduce the number of tables included in the paper, the complete set of marginal effects are not reported here. A full set of marginal effects for firms, distance, and the distance-time interaction can be found at http://ken.brevoort.com or are available from the authors upon request.
} 


\subsection{Specification II: Multiple Linear Time-Distance Trends}

The results from the model specifications that allow for separate linear time-distance trends for each of the three institution size classes are presented in Tables 9 through 11. Table 9 presents the coefficients on LnFirms for both the estimations with and without census tract fixed effects. As was the case for the estimations with a single linear time trend, the coefficients on LnFirms from the estimations that omitted census tract fixed effects are all positive and significant at levels less than 1 percent. For the estimations that included tract fixed effects the results were positive and significant at the 1 percent level for three MSAs (Atlanta, Denver, and Indianapolis) and otherwise insignificant.

\begin{tabular}{lcc}
\hline \hline MSA & No TFE & TFE \\
\hline Atlanta & 0.6537 & 0.1108 \\
& $(74.9123)$ & $(2.6743)$ \\
Denver & 0.7947 & 0.1825 \\
& $(88.3409)$ & $(4.8298)$ \\
Indianapolis & 0.5572 & 0.1173 \\
& $(53.7251)$ & $(2.8582)$ \\
Kansas City & 0.6058 & 0.0286 \\
& $(69.7280)$ & $(0.8097)$ \\
Nashville & 0.4800 & -0.0000 \\
& $(24.8984)$ & $(-0.0006)$ \\
Providence & 0.4907 & 0.0810 \\
& $(42.5195)$ & $(1.4543)$ \\
Rochester & 0.7664 & -0.0813 \\
& $(46.6711)$ & $(-0.9246)$ \\
San Antonio & 0.6103 & -0.0013 \\
& $(46.5209)$ & $(-0.0251)$ \\
Seattle & 0.5299 & 0.0642 \\
& $(65.8874)$ & $(1.9223)$ \\
\hline \hline
\end{tabular}

Notes: TFE denotes the coefficients are from estimations that employed census tract fixed effects. T-statistics are in parentheses. As with McMillen (1992), the standard errors used to calculate the t-statistics in the estimations with spatially-dependent errors are conditional on $\rho$ and so that the t-statistics overestimate the unconditional t-statistics.

Table 9: Coefficients on Log Number of Firms in Estimations with Spatially-Correlated Errors and Multiple Time-Distance Trends

As with the coefficients on LnFirms, the coefficients on $L n D$ in estimations with multiple 
linear time-distance trends tell a very consistent story (Table 10). Indeed, the coefficients from the multiple time-distance trend estimations exhibit the same general pattern as the coefficients from the estimations where a single time-distance trend was estimated. Specifically, in all cases distance has a statistically significant negative impact on the probability that a bank will extend credit to a census tract. Furthermore, once again distance is less of a deterrent to bank lending at medium-sized institutions than at smaller institutions for every MSA but Providence. And in all cases distance has a greater deterrent effect at large banks than at small or medium banks.

\begin{tabular}{l|ccc|ccc}
\hline \hline & & No TFE & & \multicolumn{3}{c}{ TFE } \\
& LnD & LnD*M & LnD*L & LnD & LnD*M & LnD*L \\
\hline Atlanta & -1.7618 & 1.1447 & 1.6101 & -1.6532 & 0.8029 & 1.0525 \\
& $(-46.9569)$ & $(21.4704)$ & $(33.0718)$ & $(-45.8293)$ & $(15.5226)$ & $(22.1860)$ \\
Denver & -0.7452 & 0.0902 & 0.7203 & -0.9946 & 0.0001 & 0.5771 \\
& $(-40.1410)$ & $(2.8614)$ & $(22.0695)$ & $(-51.6661)$ & $(0.0039)$ & $(18.1084)$ \\
Indianapolis & -1.3793 & 0.7811 & 0.8895 & -1.4207 & 0.6266 & 0.6297 \\
& $(-19.8564)$ & $(10.4609)$ & $(10.9960)$ & $(-20.1897)$ & $(8.3009)$ & $(7.7856)$ \\
Kansas City & -0.7637 & 0.2481 & 0.4965 & -0.9806 & 0.1587 & 0.3876 \\
Nashville & $(-26.9537)$ & $(6.0592)$ & $(11.7880)$ & $(-33.5189)$ & $(3.9059)$ & $(9.2515)$ \\
& -0.5903 & 0.3547 & 0.3841 & -0.8478 & 0.1583 & 0.1883 \\
Providence & $(-5.4015)$ & $(2.7338)$ & $(3.1889)$ & $(-8.0416)$ & $(1.2661)$ & $(1.6022)$ \\
& -0.7539 & -0.2442 & 0.3041 & -1.0437 & -0.1352 & 0.2010 \\
Rochester & $(-13.0527)$ & $(-3.7464)$ & $(4.2719)$ & $(-18.3909)$ & $(-2.1198)$ & $(2.9247)$ \\
& -1.6262 & 0.6435 & 1.1273 & -1.7515 & 0.5861 & 0.8798 \\
San Antonio & $(-19.9808)$ & $(6.8103)$ & $(11.1606)$ & $(-20.9051)$ & $(5.9812)$ & $(8.4752)$ \\
Seattle & -0.6775 & 0.2749 & 0.5474 & -0.8748 & 0.1784 & 0.3468 \\
& $(-8.5623)$ & $(3.0136)$ & $(6.1856)$ & $(-10.8117)$ & $(1.9613)$ & $(3.8945)$ \\
& -1.0782 & 0.4812 & 0.7931 & -1.1833 & 0.4121 & 0.5772 \\
& $(-32.4111)$ & $(10.6834)$ & $(18.4302)$ & $(-34.1836)$ & $(8.9494)$ & $(12.9643)$ \\
\hline \hline
\end{tabular}

Notes: TFE denotes the coefficients are from estimations that employed census tract fixed effects. T-statistics are in parentheses. As with McMillen (1992), the standard errors used to calculate the t-statistics in the estimations with spatially-dependent errors are conditional on $\rho$ and so that the t-statistics overestimate the unconditional t-statistics.

Table 10: Coefficients on Log Distance in Estimations with Spatially-Correlated Errors and Multiple Time-Distance Trends

While the coefficients on the time-distance trend variables exhibit a pattern that is similar to the results from the estimations that employed a single time-distance trend (Table 11), the results vary across bank size categories and MSAs. For small banks, the time-distance coefficient was positive and significant at the one percent level for the Indianapolis estimations, negative 
and significant for Nashville, Providence, and the Kansas City estimation without tract fixed effects, and otherwise statistically insignificant and of mixed sign.

\begin{tabular}{l|ccc|ccc}
\hline \hline & \multicolumn{3}{|c|}{ No TFE } & \multicolumn{3}{c}{ TFE } \\
& LnD*T*S & LnD*T*M & LnD*T*L & LnD*T*S & LnD $^{*} \mathrm{~T}^{*} \mathrm{M}$ & LnD $^{*} \mathrm{~T}^{*} \mathrm{~L}$ \\
\hline Atlanta & 0.0217 & -0.0817 & -0.0542 & -0.0181 & -0.0760 & -0.0590 \\
& $(1.7094)$ & $(-5.8088)$ & $(-6.3744)$ & $(-1.4826)$ & $(-5.7407)$ & $(-7.0179)$ \\
Denver & -0.0075 & 0.0798 & -0.0717 & -0.0106 & 0.0861 & -0.0701 \\
& $(-1.0739)$ & $(8.6400)$ & $(-8.0947)$ & $(-1.6017)$ & $(9.6349)$ & $(-8.0239)$ \\
Kndianapolis & 0.1066 & -0.0092 & 0.0738 & 0.0988 & -0.0096 & -0.0963 \\
& $(4.8676)$ & $(-0.7228)$ & $(5.7571)$ & $(4.4911)$ & $(-0.7814)$ & $(7.6390)$ \\
Nansas City & -0.0285 & -0.0082 & -0.0153 & -0.0161 & 0.0149 & 0.0071 \\
Providence & $(-2.7012)$ & $(-0.7690)$ & $(-1.3789)$ & $(-1.5155)$ & $(1.3984)$ & $(0.6592)$ \\
& -0.1884 & -0.1873 & -0.0070 & -0.1676 & -0.1496 & 0.0143 \\
Rochester & $(-5.2946)$ & $(-5.7347)$ & $(-0.3835)$ & $(-4.9368)$ & $(-4.6606)$ & $(0.7834)$ \\
& -0.0650 & -0.0177 & -0.0462 & -0.0583 & -0.0251 & -0.0484 \\
San Antonio & $(-3.0494)$ & $(-1.3658)$ & $(-3.3113)$ & $(-2.8395)$ & $(-1.9865)$ & $(-3.4950)$ \\
Seattle & 0.0300 & -0.0331 & -0.0146 & 0.0365 & -0.0339 & -0.0162 \\
& $(1.1377)$ & $(-1.3143)$ & $(-0.8578)$ & $(1.3651)$ & $(-1.7010)$ & $(-1.1728)$ \\
& 0.0109 & 0.0001 & -0.0515 & 0.0332 & 0.0351 & -0.0024 \\
& $(0.3910)$ & $(0.0073)$ & $(-3.4789)$ & $(1.1959)$ & $(2.1267)$ & $(-0.1625)$ \\
\hline \hline
\end{tabular}

Notes: TFE denotes the coefficients are from estimations that employed census tract fixed effects. T-statistics are in parentheses. As with McMillen (1992), the standard errors used to calculate the t-statistics in the estimations with spatially-dependent errors are conditional on $\rho$ and so that the t-statistics overestimate the unconditional t-statistics.

Table 11: Coefficients on Time*Distance in Estimations with Spatially-Correlated Errors and Multiple Time-Distance Trends

The results for medium and large banks were also more often negative when statistically significant, but again not uniformly. When significant, the time-distance effect among medium banks was negative for three cities (Atlanta, Nashville, and Seattle) and positive for one (Denver). Likewise, the time-distance effect among large banks was negative and significant across both specifications three times (Atlanta, Denver, and Providence) and positive once (Seattle). Additionally, the time-distance effect for Indianapolis was positive and significant in the estimation without tract fixed effects and negative and significant in the estimation with fixed effects.

Marginal effects were also calculated for the estimations including multiple time-distance 
effects. These marginal effects exhibit a trend that is once again very similar to the results that were estimated for the case of the single time-distance trends. Specifically, the marginal effect of a one-mile increase in the distance between a bank and a census tract with characteristics equal to the sample means (presented in Table 4) is a decrease of 1.7 percentage points in the probability of extending a loan at small banks, 1.4 at medium banks, and 0.7 at large banks.

The marginal effect of a one-year increase in time are of similar magnitude to the results from the single time-distance trend results. The median effect of a one-year increase in time is an increase in the probability of a bank making a loan to a census tract of 0.06 percentage points for small banks, and decreases of 0.19 and 0.15 percentage points for medium and large banks respectively. These results suggest that any change that might be occurring in local bank lending patterns over time is relatively minor.

Neither the results for the single or multiple time-distance trend estimations support the finding that the deterrent effect of distance has been increasing over time for within-market loans. In fact, to the extent that the results of the estimations performed as part of this study provide evidence of a trend across cities, it is more often the case that distance is becoming increasingly important in local lending, although the marginal effects for the time-distance variable, for both the estimations with single and multiple trends, suggest that any such changes are likely minor. 


\section{Conclusions}

We employ annual CRA data over the period 1997 - 2001 for nine different metropolitan areas in the United States to investigate the role of distance in within-market lending and how it has changed over time. A probit model that accounts for possible spatial correlation is used to estimate the likelihood of a bank making a loan to at least one firm in each census tract in the metropolitan area, given the identity of the bank, the number of small businesses in the census tract, and the distance between the center of the census tract and the location of the nearest branch of that bank.

We find that, even within areas generally considered to represent a local market, distance between bank and census tract is negatively associated with the likelihood of a commercial loan being made. Further, this deterrent effect of distance is more important, the smaller is the size category of the bank. In other words, distance matters in explaining where a bank chooses to lend in a metropolitan area, and it matters more for smaller banks than for larger banks.

The observed changes in the role of distance over the time period examined are not as robust across metropolitan areas or size categories of the banks. However, we do find that within a majority of the metropolitan areas examined, distances between borrower and lender became even more negatively associated with the likelihood of an observed commercial loan over time, consistent with the notion that, as competition increases from lenders located outside the market, local lenders reallocate resources toward loans in which they enjoy a locational advantage.

While this study does not constitute an explicit structural test of the theoretical predictions of either Dell'Ariccia \& Marquez (forthcoming) or Hauswald \& Marquez (2002) the results presented here are, in general, consistent with their predictions. Our findings, when combined with the existing empirical literature suggest that the technological changes in credit markets are having asymmetric effects across institution size categories on the relationship between distance and lending at financial institutions. 


\section{References}

Almazan, A. (2002). A model of competition in banking: Bank capital vs. expertise, Journal of Financial Intermediation 11: 87-121.

Amemiya, T. (1985). Advanced Econometrics, Harvard University Press.

Anselin, L. (1998). Gis research infrastructure for spatial analysis of real estate markets, Journal of Housing Research 9(1): 113-133.

Berger, A. N. \& Hannan, T. H. (1989). The price-concentration relationship in banking, The Review of Economics and Statistics 71(2): 291-299.

Berger, A. N. \& Udell, G. F. (1995). Relationship lending and lines of credit in small firm finance, The Journal of Business 68(3): 351-381.

Berger, A. N. \& Udell, G. F. (1998). The economics of small business finance: The roles of private equity and debt markets in the financial growth cycle, Journal of Banking and Finance 22(6-8): 613-673.

Boot, A. W. A. (2000). Relationship banking: What do we know?, Journal of Financial Intermediation 9: 7-25.

Calem, P. S. \& Carlino, G. A. (1991). The concentration/conduct relationship in bank deposit markets, The Review of Economics and Statistics 73(2): 268-276.

Chiappori, P.-A., Perez-Castrillo, D. \& Verdier, T. (1995). Spatial competition in the banking system: Localization, cross subsidies and the regulation of deposit rates, European Economic Review 39(5): 889-918.

Degryse, H. \& Ongena, S. (2002). Distance, lending relationships, and competition. Mimeo.

Dell'Ariccia, G. \& Marquez, R. (forthcoming). Information and bank credit allocation, Journal of Financial Economics .

Hannan, T. H. (1991). Bank commercial loan markets and the role of market structure: Evidence from surveys of commercial lending, Journal of Banking and Finance 15: 133-149. 
Hauswald, R. \& Marquez, R. (2002). Competition and strategic information acquisition in credit markets. Mimeo.

Kiser, E. K. (forthcoming). Modeling the whole firm: The effect of multiple inputs and financial intermediation on bank deposit rates. FEDS Working Paper.

Kwast, M. L., Starr-McCluer, M. \& Wolken, J. D. (1997). Market definition and the analysis of antitrust in banking, The Antitrust Bulletin .

LeSage, J. P. (1998). Spatial econometrics. Mimeo available at http://www.spatialeconometrics.com.

McMillen, D. P. (1992). Probit with spatial autocorrelation, Journal of Regional Science 32(3): $335-348$.

Park, K. \& Pennacchi, G. (2003). Harming depositors and helping borrowers: The disparate impact of bank consolidation. Mimeo.

Petersen, M. A. \& Rajan, R. G. (2000). Does distance still matter? the information revolution in small business lending. NBER Working Paper No. 7685.

Petersen, M. A. \& Rajan, R. G. (2002). Does distance still matter? the information revolution in small business lending, Journal of Finance 57: 2533-2570.

Scott, J. A. (2003). Credit, banks and small business - the new century. Mimeo.

Wolken, J. \& Rohde, D. (2002). Changes in the location of small businesses' financial services suppliers between 1993 and 1998. Federal Reserve Board Memo. 


\section{Appendix}

\begin{tabular}{|c|c|c|c|c|c|c|c|c|}
\hline & $\overline{\bar{I}}$ & $\overline{\mathrm{III}}$ & $\overline{\overline{\text { III }}}$ & $\overline{\mathrm{IV}}$ & $\overline{\mathrm{II}}$ & II & III & IV \\
\hline $\begin{array}{l}\text { Spatial Er- } \\
\text { rors }\end{array}$ & $\mathrm{Y}$ & $\mathrm{N}$ & $\mathrm{Y}$ & $\mathrm{N}$ & $\mathrm{Y}$ & $\mathrm{N}$ & $\mathrm{Y}$ & $\mathrm{N}$ \\
\hline Tract FE & $\mathrm{N}$ & $\mathrm{N}$ & Y & Y & $\mathrm{N}$ & $\mathrm{N}$ & Y & Y \\
\hline Bank FE & $\mathrm{Y}$ & Y & Y & Y & $\mathrm{Y}$ & Y & $\mathrm{Y}$ & Y \\
\hline Constant & $\begin{array}{c}-0.169 \\
(-2.975)\end{array}$ & $\begin{array}{l}-0.451 \\
(-6.240)\end{array}$ & $\begin{array}{c}0.262 \\
(1.768)\end{array}$ & $\begin{array}{c}-0.050 \\
(-0.309)\end{array}$ & $\begin{array}{l}-0.168 \\
(-2.891)\end{array}$ & $\begin{array}{c}-0.440 \\
(-6.118)\end{array}$ & $\begin{array}{c}0.268 \\
(1.805)\end{array}$ & $\begin{array}{c}-0.038 \\
(-0.232)\end{array}$ \\
\hline D1998 & $\begin{array}{c}-0.192 \\
(-6.794)\end{array}$ & $\begin{array}{c}-0.161 \\
(-6.372)\end{array}$ & $\begin{array}{c}0.024 \\
(0.749)\end{array}$ & $\begin{array}{c}0.040 \\
(1.221)\end{array}$ & $\begin{array}{c}-0.202 \\
(-6.953)\end{array}$ & $\begin{array}{c}-0.177 \\
(-6.898)\end{array}$ & $\begin{array}{c}0.015 \\
(0.452)\end{array}$ & $\begin{array}{c}0.028 \\
(0.837)\end{array}$ \\
\hline D1999 & $\begin{array}{c}-0.217 \\
(-7.731)\end{array}$ & $\begin{array}{c}-0.182 \\
(-7.002)\end{array}$ & $\begin{array}{c}0.096 \\
(2.740)\end{array}$ & $\begin{array}{c}0.105 \\
(2.723)\end{array}$ & $\begin{array}{c}-0.237 \\
(-7.786)\end{array}$ & $\begin{array}{c}-0.212 \\
(-7.844)\end{array}$ & $\begin{array}{c}0.080 \\
(2.182)\end{array}$ & $\begin{array}{c}0.084 \\
(2.123)\end{array}$ \\
\hline D2000 & $\begin{array}{c}-0.307 \\
(-10.495)\end{array}$ & $\begin{array}{c}-0.270 \\
(-9.727)\end{array}$ & $\begin{array}{c}0.122 \\
(2.992)\end{array}$ & $\begin{array}{c}0.124 \\
(2.659)\end{array}$ & $\begin{array}{c}-0.341 \\
(-9.940)\end{array}$ & $\begin{array}{c}-0.318 \\
(-10.739)\end{array}$ & $\begin{array}{c}0.096 \\
(2.186)\end{array}$ & $\begin{array}{c}0.091 \\
(1.873)\end{array}$ \\
\hline D2001 & $\begin{array}{l}-0.290 \\
(-9.898)\end{array}$ & $\begin{array}{c}-0.250 \\
(-8.770)\end{array}$ & $\begin{array}{c}0.220 \\
(4.951)\end{array}$ & $\begin{array}{c}0.219 \\
(4.203)\end{array}$ & $\begin{array}{c}-0.332 \\
(-9.007)\end{array}$ & $\begin{array}{c}-0.311 \\
(-9.972)\end{array}$ & $\begin{array}{c}0.189 \\
(3.845)\end{array}$ & $\begin{array}{c}0.177 \\
(3.263)\end{array}$ \\
\hline LnD & $\begin{array}{c}-1.601 \\
(-61.493)\end{array}$ & $\begin{array}{c}-1.457 \\
(-53.763)\end{array}$ & $\begin{array}{c}-1.567 \\
(-61.226)\end{array}$ & $\begin{array}{c}-1.425 \\
(-51.659)\end{array}$ & $\begin{array}{c}-1.762 \\
(-46.957)\end{array}$ & $\begin{array}{c}-1.631 \\
(-37.773)\end{array}$ & $\begin{array}{c}-1.653 \\
(-45.829)\end{array}$ & $\begin{array}{c}-1.516 \\
(-34.994)\end{array}$ \\
\hline $\mathrm{LnD}^{*} \mathrm{M}$ & $\begin{array}{c}0.910 \\
(27.689)\end{array}$ & $\begin{array}{c}0.879 \\
(28.104)\end{array}$ & $\begin{array}{c}0.669 \\
(20.688)\end{array}$ & $\begin{array}{c}0.636 \\
(19.689)\end{array}$ & $\begin{array}{c}1.145 \\
(21.470)\end{array}$ & $\begin{array}{c}1.114 \\
(20.417)\end{array}$ & $\begin{array}{c}0.803 \\
(15.523)\end{array}$ & $\begin{array}{c}0.759 \\
(13.511)\end{array}$ \\
\hline $\mathrm{LnD}^{*} \mathrm{~L}$ & $\begin{array}{c}1.437 \\
(47.714)\end{array}$ & $\begin{array}{c}1.204 \\
(43.127)\end{array}$ & $\begin{array}{c}0.958 \\
(31.789)\end{array}$ & $\begin{array}{c}0.742 \\
(24.722)\end{array}$ & $\begin{array}{c}1.610 \\
(33.072)\end{array}$ & $\begin{array}{c}1.404 \\
(28.838)\end{array}$ & $\begin{array}{c}1.053 \\
(22.186)\end{array}$ & $\begin{array}{c}0.851 \\
(16.795)\end{array}$ \\
\hline $\mathrm{LnD}^{*} \mathrm{~T}$ & $\begin{array}{c}-0.048 \\
(-8.539)\end{array}$ & $\begin{array}{c}-0.057 \\
(-10.357)\end{array}$ & $\begin{array}{c}-0.055 \\
(-10.105)\end{array}$ & $\begin{array}{c}-0.064 \\
(-10.933)\end{array}$ & & & & \\
\hline $\operatorname{LnD}^{*} \mathrm{~T}^{*} \mathrm{~S}$ & & & & & $\begin{array}{c}0.022 \\
(1.709)\end{array}$ & $\begin{array}{c}0.018 \\
(1.181)\end{array}$ & $\begin{array}{c}-0.018 \\
(-1.483)\end{array}$ & $\begin{array}{c}-0.025 \\
(-1.649)\end{array}$ \\
\hline $\mathrm{LnD}^{*} \mathrm{~T}^{*} \mathrm{M}$ & & & & & $\begin{array}{c}-0.082 \\
(-5.809)\end{array}$ & $\begin{array}{c}-0.085 \\
(-7.404)\end{array}$ & $\begin{array}{c}-0.076 \\
(-5.741)\end{array}$ & $\begin{array}{c}-0.078 \\
(-6.520)\end{array}$ \\
\hline $\mathrm{LnD}^{*} \mathrm{~T}^{*} \mathrm{~L}$ & & & & & $\begin{array}{c}-0.054 \\
(-6.374)\end{array}$ & $\begin{array}{c}-0.070 \\
(-9.972)\end{array}$ & $\begin{array}{c}-0.059 \\
(-7.018)\end{array}$ & $\begin{array}{c}-0.072 \\
(-9.513)\end{array}$ \\
\hline LnFirms & $\begin{array}{c}0.653 \\
(74.902)\end{array}$ & $\begin{array}{c}0.608 \\
(64.791)\end{array}$ & $\begin{array}{c}0.102 \\
(2.467)\end{array}$ & $\begin{array}{c}0.105 \\
(2.218)\end{array}$ & $\begin{array}{c}0.654 \\
(74.912)\end{array}$ & $\begin{array}{c}0.609 \\
(64.842)\end{array}$ & $\begin{array}{c}0.111 \\
(2.674)\end{array}$ & $\begin{array}{c}0.114 \\
(2.388)\end{array}$ \\
\hline rho & 0.500 & & 0.439 & & 0.499 & & 0.439 & \\
\hline
\end{tabular}

Notes: T-statistics are in parentheses. As with McMillen (1992), the standard errors used to calculate the t-statistics in the estimations with spatially-dependent errors are conditional on $\rho$ and so that the t-statistics overestimate the unconditional t-statistics.

Table 12: SDE Probit Estimates - Atlanta 


\begin{tabular}{|c|c|c|c|c|c|c|c|c|}
\hline & $\overline{\overline{\mathrm{I}}}$ & $\overline{\overline{\text { II }}}$ & $\overline{\overline{\text { III }}}$ & $\overline{\mathrm{IV}}$ & I & $\overline{\overline{\text { II }}}$ & III & $\overline{\overline{I V}}$ \\
\hline $\begin{array}{l}\text { Spatial Er- } \\
\text { rors }\end{array}$ & $\bar{Y}$ & $\mathrm{~N}$ & $\bar{Y}$ & $\mathrm{~N}$ & $\bar{Y}$ & $\mathrm{~N}$ & $\bar{Y}$ & $\mathrm{~N}$ \\
\hline Tract FE & $\mathrm{N}$ & $\mathrm{N}$ & Y & Y & $\mathrm{N}$ & $\mathrm{N}$ & Y & Y \\
\hline Bank FE & Y & Y & Y & Y & Y & Y & Y & Y \\
\hline Constant & $\begin{array}{c}-0.204 \\
(-3.563)\end{array}$ & $\begin{array}{c}-0.691 \\
(-20.151)\end{array}$ & $\begin{array}{c}-1.048 \\
(-7.976)\end{array}$ & $\begin{array}{c}-1.436 \\
(-8.341)\end{array}$ & $\begin{array}{c}-0.214 \\
(-3.744)\end{array}$ & $\begin{array}{c}-0.686 \\
(-19.837)\end{array}$ & $\begin{array}{c}-1.057 \\
(-8.022)\end{array}$ & $\begin{array}{c}-1.427 \\
(-8.215)\end{array}$ \\
\hline D1998 & $\begin{array}{c}0.047 \\
(2.289)\end{array}$ & $\begin{array}{c}0.037 \\
(1.657)\end{array}$ & $\begin{array}{c}0.046 \\
(2.239)\end{array}$ & $\begin{array}{c}0.038 \\
(1.591)\end{array}$ & $\begin{array}{c}0.033 \\
(1.599)\end{array}$ & $\begin{array}{c}0.025 \\
(1.112)\end{array}$ & $\begin{array}{c}0.033 \\
(1.619)\end{array}$ & $\begin{array}{c}0.027 \\
(1.128)\end{array}$ \\
\hline D1999 & $\begin{array}{c}0.019 \\
(0.916)\end{array}$ & $\begin{array}{c}0.013 \\
(0.571)\end{array}$ & $\begin{array}{c}0.074 \\
(3.545)\end{array}$ & $\begin{array}{l}0.063 \\
(2.534)\end{array}$ & $\begin{array}{c}-0.005 \\
(-0.257)\end{array}$ & $\begin{array}{c}-0.009 \\
(-0.413)\end{array}$ & $\begin{array}{c}0.052 \\
(2.497)\end{array}$ & $\begin{array}{c}0.043 \\
(1.729)\end{array}$ \\
\hline D2000 & $\begin{array}{c}-0.155 \\
(-7.584)\end{array}$ & $\begin{array}{l}-0.145 \\
(-6.124)\end{array}$ & $\begin{array}{c}-0.038 \\
(-1.705)\end{array}$ & $\begin{array}{c}-0.041 \\
(-1.436)\end{array}$ & $\begin{array}{c}-0.180 \\
(-8.527)\end{array}$ & $\begin{array}{c}-0.169 \\
(-7.120)\end{array}$ & $\begin{array}{c}-0.059 \\
(-2.593)\end{array}$ & $\begin{array}{c}-0.061 \\
(-2.154)\end{array}$ \\
\hline D2001 & $\begin{array}{c}-0.114 \\
(-5.475)\end{array}$ & $\begin{array}{c}-0.116 \\
(-4.766)\end{array}$ & $\begin{array}{c}0.077 \\
(3.047)\end{array}$ & $\begin{array}{c}0.058 \\
(1.771)\end{array}$ & $\begin{array}{c}-0.141 \\
(-6.407)\end{array}$ & $\begin{array}{c}-0.142 \\
(-5.834)\end{array}$ & $\begin{array}{c}0.056 \\
(2.164)\end{array}$ & $\begin{array}{c}0.037 \\
(1.128)\end{array}$ \\
\hline LnD & $\begin{array}{c}-0.764 \\
(-52.091)\end{array}$ & $\begin{array}{c}-0.653 \\
(-43.481)\end{array}$ & $\begin{array}{c}-1.025 \\
(-63.670)\end{array}$ & $\begin{array}{c}-0.914 \\
(-54.673)\end{array}$ & $\begin{array}{c}-0.745 \\
(-40.141)\end{array}$ & $\begin{array}{c}-0.632 \\
(-33.132)\end{array}$ & $\begin{array}{c}-0.995 \\
(-51.666)\end{array}$ & $\begin{array}{c}-0.882 \\
(-42.896)\end{array}$ \\
\hline $\operatorname{LnD}^{*} \mathrm{M}$ & $\begin{array}{c}0.282 \\
(13.525)\end{array}$ & $\begin{array}{c}0.191 \\
(10.994)\end{array}$ & $\begin{array}{c}0.215 \\
(10.536)\end{array}$ & $\begin{array}{c}0.148 \\
(8.081)\end{array}$ & $\begin{array}{c}0.090 \\
(2.861)\end{array}$ & $\begin{array}{c}-0.004 \\
(-0.150)\end{array}$ & $\begin{array}{l}0.0001 \\
(0.004)\end{array}$ & $\begin{array}{c}-0.067 \\
(-2.241)\end{array}$ \\
\hline $\mathrm{LnD}^{*} \mathrm{~L}$ & $\begin{array}{c}0.585 \\
(27.507)\end{array}$ & $\begin{array}{c}0.446 \\
(23.137)\end{array}$ & $\begin{array}{c}0.450 \\
(21.402)\end{array}$ & $\begin{array}{c}0.341 \\
(16.293)\end{array}$ & $\begin{array}{c}0.720 \\
(22.070)\end{array}$ & $\begin{array}{c}0.590 \\
(19.768)\end{array}$ & $\begin{array}{c}0.577 \\
(18.108)\end{array}$ & $\begin{array}{c}0.475 \\
(14.904)\end{array}$ \\
\hline $\mathrm{LnD}^{*} \mathrm{~T}$ & $\begin{array}{c}0.001 \\
(0.135)\end{array}$ & $\begin{array}{c}-0.001 \\
(-0.260)\end{array}$ & $\begin{array}{c}0.003 \\
(0.576)\end{array}$ & $\begin{array}{c}0.001 \\
(0.158)\end{array}$ & & & & \\
\hline $\operatorname{LnD} * \mathrm{~T}^{*} \mathrm{~S}$ & & & & & $\begin{array}{l}-0.008 \\
(-1.074)\end{array}$ & $\begin{array}{c}-0.011 \\
(-1.526)\end{array}$ & $\begin{array}{c}-0.011 \\
(-1.602)\end{array}$ & $\begin{array}{c}-0.013 \\
(-1.809)\end{array}$ \\
\hline $\mathrm{LnD}^{*} \mathrm{~T}^{*} \mathrm{M}$ & & & & & $\begin{array}{c}0.080 \\
(8.640)\end{array}$ & $\begin{array}{c}0.078 \\
(9.901)\end{array}$ & $\begin{array}{c}0.086 \\
(9.635)\end{array}$ & $\begin{array}{c}0.084 \\
(10.181)\end{array}$ \\
\hline $\mathrm{LnD}^{*} \mathrm{~T}^{*} \mathrm{~L}$ & & & & & $\begin{array}{c}-0.072 \\
(-8.095)\end{array}$ & $\begin{array}{c}-0.078 \\
(-9.480)\end{array}$ & $\begin{array}{c}-0.070 \\
(-8.024)\end{array}$ & $\begin{array}{l}-0.075 \\
(-8.646)\end{array}$ \\
\hline LnFirms & $\begin{array}{c}0.792 \\
(88.213)\end{array}$ & $\begin{array}{c}0.727 \\
(65.750)\end{array}$ & $\begin{array}{c}0.193 \\
(5.106)\end{array}$ & $\begin{array}{c}0.183 \\
(3.739)\end{array}$ & $\begin{array}{c}0.795 \\
(88.341)\end{array}$ & $\begin{array}{c}0.729 \\
(65.895)\end{array}$ & $\begin{array}{c}0.183 \\
(4.830)\end{array}$ & $\begin{array}{c}0.174 \\
(3.571)\end{array}$ \\
\hline rho & 0.411 & & 0.348 & & 0.410 & & 0.347 & \\
\hline
\end{tabular}

Notes: T-statistics are in parentheses. As with McMillen (1992), the standard errors used to calculate the t-statistics in the estimations with spatially-dependent errors are conditional on $\rho$ and so that the t-statistics overestimate the unconditional t-statistics.

Table 13: SDE Probit Estimates - Denver 


\begin{tabular}{|c|c|c|c|c|c|c|c|c|}
\hline & $\overline{\overline{\mathrm{I}}}$ & $\overline{\overline{\text { II }}}$ & $\overline{\overline{\text { III }}}$ & $\overline{\mathrm{IV}}$ & I & $\overline{\overline{\text { II }}}$ & III & $\overline{\overline{I V}}$ \\
\hline $\begin{array}{l}\text { Spatial Er- } \\
\text { rors }\end{array}$ & $\bar{Y}$ & $\mathrm{~N}$ & $\bar{Y}$ & $\mathrm{~N}$ & $\bar{Y}$ & $\mathrm{~N}$ & $\bar{Y}$ & $\mathrm{~N}$ \\
\hline Tract FE & $\mathrm{N}$ & $\mathrm{N}$ & Y & Y & $\mathrm{N}$ & $\mathrm{N}$ & Y & Y \\
\hline Bank FE & Y & Y & Y & Y & Y & Y & Y & Y \\
\hline Constant & $\begin{array}{c}-0.019 \\
(-0.258)\end{array}$ & $\begin{array}{c}-0.514 \\
(-12.678)\end{array}$ & $\begin{array}{c}0.494 \\
(2.548)\end{array}$ & $\begin{array}{c}-0.040 \\
(-0.248)\end{array}$ & $\begin{array}{c}-0.032 \\
(-0.432)\end{array}$ & $\begin{array}{c}-0.533 \\
(-13.074)\end{array}$ & $\begin{array}{c}0.475 \\
(2.439)\end{array}$ & $\begin{array}{c}-0.067 \\
(-0.416)\end{array}$ \\
\hline D1998 & $\begin{array}{c}0.147 \\
(3.796)\end{array}$ & $\begin{array}{c}0.130 \\
(4.173)\end{array}$ & $\begin{array}{c}0.169 \\
(4.542)\end{array}$ & $\begin{array}{c}0.156 \\
(4.803)\end{array}$ & $\begin{array}{c}0.151 \\
(3.829)\end{array}$ & $\begin{array}{c}0.139 \\
(4.432)\end{array}$ & $\begin{array}{c}0.176 \\
(4.680)\end{array}$ & $\begin{array}{c}0.167 \\
(5.125)\end{array}$ \\
\hline D1999 & $\begin{array}{c}0.164 \\
(4.220)\end{array}$ & $\begin{array}{c}0.136 \\
(4.204)\end{array}$ & $\begin{array}{c}0.238 \\
(6.253)\end{array}$ & $\begin{array}{c}0.209 \\
(6.062)\end{array}$ & $\begin{array}{c}0.172 \\
(4.259)\end{array}$ & $\begin{array}{c}0.151 \\
(4.649)\end{array}$ & $\begin{array}{c}0.252 \\
(6.468)\end{array}$ & $\begin{array}{c}0.230 \\
(6.619)\end{array}$ \\
\hline D2000 & $\begin{array}{c}0.127 \\
(3.216)\end{array}$ & $\begin{array}{c}0.086 \\
(2.603)\end{array}$ & $\begin{array}{c}0.283 \\
(6.993)\end{array}$ & $\begin{array}{c}0.240 \\
(6.318)\end{array}$ & $\begin{array}{c}0.141 \\
(3.287)\end{array}$ & $\begin{array}{c}0.111 \\
(3.325)\end{array}$ & $\begin{array}{c}0.311 \\
(7.218)\end{array}$ & $\begin{array}{c}0.278 \\
(7.201)\end{array}$ \\
\hline D2001 & $\begin{array}{c}0.038 \\
(0.967)\end{array}$ & $\begin{array}{c}-0.005 \\
(-0.142)\end{array}$ & $\begin{array}{c}0.220 \\
(5.275)\end{array}$ & $\begin{array}{c}0.174 \\
(4.338)\end{array}$ & $\begin{array}{c}0.055 \\
(1.203)\end{array}$ & $\begin{array}{c}0.026 \\
(0.760)\end{array}$ & $\begin{array}{c}0.255 \\
(5.471)\end{array}$ & $\begin{array}{c}0.222 \\
(5.380)\end{array}$ \\
\hline LnD & $\begin{array}{c}-1.203 \\
(-30.124)\end{array}$ & $\begin{array}{c}-1.071 \\
(-27.468)\end{array}$ & $\begin{array}{c}-1.299 \\
(-32.157)\end{array}$ & $\begin{array}{c}-1.165 \\
(-28.587)\end{array}$ & $\begin{array}{c}-1.379 \\
(-19.856)\end{array}$ & $\begin{array}{c}-1.219 \\
(-13.957)\end{array}$ & $\begin{array}{c}-1.421 \\
(-20.190)\end{array}$ & $\begin{array}{c}-1.256 \\
(-14.138\end{array}$ \\
\hline $\operatorname{LnD}^{*} \mathrm{M}$ & $\begin{array}{c}0.505 \\
(12.374)\end{array}$ & $\begin{array}{c}0.427 \\
(11.062)\end{array}$ & $\begin{array}{c}0.385 \\
(9.440)\end{array}$ & $\begin{array}{c}0.321 \\
(7.956)\end{array}$ & $\begin{array}{c}0.781 \\
(10.461)\end{array}$ & $\begin{array}{c}0.680 \\
(7.457)\end{array}$ & $\begin{array}{c}0.627 \\
(8.301)\end{array}$ & $\begin{array}{l}0.535 \\
(5.747)\end{array}$ \\
\hline $\mathrm{LnD}^{*} \mathrm{~L}$ & $\begin{array}{c}0.779 \\
(18.531)\end{array}$ & $\begin{array}{c}0.582 \\
(15.493)\end{array}$ & $\begin{array}{c}0.599 \\
(14.341)\end{array}$ & $\begin{array}{c}0.429 \\
(10.716)\end{array}$ & $\begin{array}{c}0.890 \\
(10.996)\end{array}$ & $\begin{array}{c}0.643 \\
(7.004)\end{array}$ & $\begin{array}{c}0.630 \\
(7.786)\end{array}$ & $\begin{array}{c}0.408 \\
(4.335)\end{array}$ \\
\hline $\mathrm{LnD}^{*} \mathrm{~T}$ & $\begin{array}{c}0.044 \\
(5.557)\end{array}$ & $\begin{array}{c}0.042 \\
(6.028)\end{array}$ & $\begin{array}{c}0.055 \\
(7.060)\end{array}$ & $\begin{array}{c}0.053 \\
(7.204)\end{array}$ & & & & \\
\hline $\operatorname{LnD} * \mathrm{~T}^{*} \mathrm{~S}$ & & & & & $\begin{array}{c}0.107 \\
(4.868)\end{array}$ & $\begin{array}{c}0.095 \\
(3.316)\end{array}$ & $\begin{array}{c}0.099 \\
(4.491)\end{array}$ & $\begin{array}{l}0.086 \\
(2.954)\end{array}$ \\
\hline $\mathrm{LnD}^{*} \mathrm{~T}^{*} \mathrm{M}$ & & & & & $\begin{array}{c}-0.009 \\
(-0.723)\end{array}$ & $\begin{array}{c}-0.014 \\
(-1.320)\end{array}$ & $\begin{array}{c}-0.010 \\
(-0.781)\end{array}$ & $\begin{array}{c}-0.013 \\
(-1.167)\end{array}$ \\
\hline $\mathrm{LnD}^{*} \mathrm{~T}^{*} \mathrm{~L}$ & & & & & $\begin{array}{c}0.074 \\
(5.757)\end{array}$ & $\begin{array}{c}0.083 \\
(8.411)\end{array}$ & $\begin{array}{c}0.096 \\
(7.639)\end{array}$ & $\begin{array}{c}0.105 \\
(10.149)\end{array}$ \\
\hline LnFirms & $\begin{array}{c}0.557 \\
(53.723)\end{array}$ & $\begin{array}{c}0.533 \\
(53.436)\end{array}$ & $\begin{array}{c}0.129 \\
(3.143)\end{array}$ & $\begin{array}{c}0.124 \\
(3.207)\end{array}$ & $\begin{array}{c}0.557 \\
(53.725)\end{array}$ & $\begin{array}{c}0.533 \\
(53.440)\end{array}$ & $\begin{array}{c}0.117 \\
(2.858)\end{array}$ & $\begin{array}{c}0.112 \\
(2.883)\end{array}$ \\
\hline rho & 0.357 & & 0.317 & & 0.356 & & 0.313 & \\
\hline
\end{tabular}

Notes: T-statistics are in parentheses. As with McMillen (1992), the standard errors used to calculate the t-statistics in the estimations with spatially-dependent errors are conditional on $\rho$ and so that the t-statistics overestimate the unconditional t-statistics.

Table 14: SDE Probit Estimates - Indianapolis 


\begin{tabular}{|c|c|c|c|c|c|c|c|c|}
\hline & $\overline{\mathrm{I}}$ & $\overline{\mathrm{II}}$ & $\overline{\text { III }}$ & $\overline{\mathrm{IV}}$ & 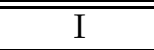 & $\overline{\mathrm{II}}$ & III & IV \\
\hline $\begin{array}{l}\text { Spatial Er- } \\
\text { rors }\end{array}$ & $\bar{Y}$ & $\mathrm{~N}$ & $\bar{Y}$ & $\mathrm{~N}$ & $\bar{Y}$ & $\mathrm{~N}$ & $\bar{Y}$ & $\mathrm{~N}$ \\
\hline Tract FE & $\mathrm{N}$ & $\mathrm{N}$ & Y & Y & $\mathrm{N}$ & $\mathrm{N}$ & Y & $\mathrm{Y}$ \\
\hline Bank FE & $\mathrm{Y}$ & $\mathrm{Y}$ & Y & Y & Y & Y & Y & $\mathrm{Y}$ \\
\hline Constant & $\begin{array}{c}-1.587 \\
(-32.799)\end{array}$ & $\begin{array}{l}-1.7655 \\
(-27.200)\end{array}$ & $\begin{array}{c}-1.362 \\
(-8.338)\end{array}$ & $\begin{array}{c}-1.562 \\
(-10.055)\end{array}$ & $\begin{array}{c}-1.589 \\
(-32.823)\end{array}$ & $\begin{array}{c}-1.766 \\
(-27.206)\end{array}$ & $\begin{array}{c}-1.366 \\
(-8.360)\end{array}$ & $\begin{array}{c}-1.566 \\
(-10.075)\end{array}$ \\
\hline D1998 & $\begin{array}{c}0.076 \\
(2.859)\end{array}$ & $\begin{array}{c}0.061 \\
(2.361)\end{array}$ & $\begin{array}{c}0.084 \\
(3.161)\end{array}$ & $\begin{array}{c}0.070 \\
(2.574)\end{array}$ & $\begin{array}{c}0.079 \\
(2.939)\end{array}$ & $\begin{array}{c}0.062 \\
(2.417)\end{array}$ & $\begin{array}{c}0.088 \\
(3.313)\end{array}$ & $\begin{array}{c}0.073 \\
(2.690)\end{array}$ \\
\hline D1999 & $\begin{array}{c}0.028 \\
(1.030)\end{array}$ & $\begin{array}{c}0.022 \\
(0.833)\end{array}$ & $\begin{array}{c}0.126 \\
(4.527)\end{array}$ & $\begin{array}{c}0.110 \\
(3.781)\end{array}$ & $\begin{array}{c}0.032 \\
(1.160)\end{array}$ & $\begin{array}{c}0.025 \\
(0.922)\end{array}$ & $\begin{array}{c}0.133 \\
(4.730)\end{array}$ & $\begin{array}{c}0.115 \\
(3.934)\end{array}$ \\
\hline D2000 & $\begin{array}{c}-0.218 \\
(-7.748)\end{array}$ & $\begin{array}{c}-0.198 \\
(-7.012)\end{array}$ & $\begin{array}{c}0.030 \\
(0.989)\end{array}$ & $\begin{array}{c}0.026 \\
(0.742)\end{array}$ & $\begin{array}{c}-0.212 \\
(-7.351)\end{array}$ & $\begin{array}{c}-0.194 \\
(-6.819)\end{array}$ & $\begin{array}{c}0.040 \\
(1.265)\end{array}$ & $\begin{array}{c}0.032 \\
(0.934)\end{array}$ \\
\hline D2001 & $\begin{array}{c}-0.075 \\
(-2.592)\end{array}$ & $\begin{array}{c}-0.077 \\
(-2.584)\end{array}$ & $\begin{array}{c}0.210 \\
(6.388)\end{array}$ & $\begin{array}{c}0.182 \\
(4.780)\end{array}$ & $\begin{array}{c}-0.070 \\
(-2.278)\end{array}$ & $\begin{array}{c}-0.074 \\
(-2.451)\end{array}$ & $\begin{array}{c}0.220 \\
(6.467)\end{array}$ & $\begin{array}{c}0.188 \\
(4.908)\end{array}$ \\
\hline LnD & $\begin{array}{c}-0.788 \\
(-36.729)\end{array}$ & $\begin{array}{c}-0.675 \\
(-34.025)\end{array}$ & $\begin{array}{c}-1.020 \\
(-44.877)\end{array}$ & $\begin{array}{c}-0.906 \\
(-41.946)\end{array}$ & $\begin{array}{c}-0.764 \\
(-26.954)\end{array}$ & $\begin{array}{c}-0.654 \\
(-24.246)\end{array}$ & $\begin{array}{c}-0.981 \\
(-33.519)\end{array}$ & $\begin{array}{c}-0.872 \\
(-30.686)\end{array}$ \\
\hline $\operatorname{LnD}^{*} \mathrm{M}$ & $\begin{array}{c}0.292 \\
(11.432)\end{array}$ & $\begin{array}{c}0.226 \\
(9.924)\end{array}$ & $\begin{array}{c}0.226 \\
(8.926)\end{array}$ & $\begin{array}{c}0.172 \\
(7.351)\end{array}$ & $\begin{array}{c}0.248 \\
(6.059)\end{array}$ & $\begin{array}{c}0.184 \\
(4.857)\end{array}$ & $\begin{array}{c}0.159 \\
(3.906)\end{array}$ & $\begin{array}{c}0.110 \\
(2.848)\end{array}$ \\
\hline LnD*L & $\begin{array}{c}0.525 \\
(19.487)\end{array}$ & $\begin{array}{c}0.373 \\
(17.001)\end{array}$ & $\begin{array}{c}0.438 \\
(16.281)\end{array}$ & $\begin{array}{c}0.307 \\
(13.274)\end{array}$ & $\begin{array}{c}0.497 \\
(11.788)\end{array}$ & $\begin{array}{c}0.354 \\
(9.896)\end{array}$ & $\begin{array}{c}0.388 \\
(9.252)\end{array}$ & $\begin{array}{c}0.268 \\
(7.235)\end{array}$ \\
\hline $\mathrm{LnD}^{*} \mathrm{~T}$ & $\begin{array}{c}-0.017 \\
(-2.854)\end{array}$ & $\begin{array}{c}-0.018 \\
(-3.002)\end{array}$ & $\begin{array}{c}0.002 \\
(0.365)\end{array}$ & $\begin{array}{c}0.001 \\
(0.174)\end{array}$ & & & & \\
\hline $\operatorname{LnD}{ }^{*} \mathrm{~T}^{*} \mathrm{~S}$ & & & & & $\begin{array}{c}-0.029 \\
(-2.701)\end{array}$ & $\begin{array}{c}-0.027 \\
(-2.624)\end{array}$ & $\begin{array}{c}-0.016 \\
(-1.516)\end{array}$ & $\begin{array}{c}-0.015 \\
(-1.391)\end{array}$ \\
\hline $\mathrm{LnD}^{*} \mathrm{~T}^{*} \mathrm{M}$ & & & & & $\begin{array}{c}-0.008 \\
(-0.769)\end{array}$ & $\begin{array}{c}-0.007 \\
(-0.734)\end{array}$ & $\begin{array}{c}0.015 \\
(1.398)\end{array}$ & $\begin{array}{c}0.014 \\
(1.365)\end{array}$ \\
\hline $\mathrm{LnD}^{*} \mathrm{~T}^{*} \mathrm{~L}$ & & & & & $\begin{array}{c}-0.015 \\
(-1.379)\end{array}$ & $\begin{array}{c}-0.018 \\
(-2.096)\end{array}$ & $\begin{array}{c}0.007 \\
(0.659)\end{array}$ & $\begin{array}{c}0.003 \\
(0.350)\end{array}$ \\
\hline LnFirms & $\begin{array}{c}0.606 \\
(69.725)\end{array}$ & $\begin{array}{c}0.546 \\
(59.288)\end{array}$ & $\begin{array}{c}0.028 \\
(0.780)\end{array}$ & $\begin{array}{c}0.021 \\
(0.511)\end{array}$ & $\begin{array}{c}0.606 \\
(69.728)\end{array}$ & $\begin{array}{c}0.546 \\
(59.298)\end{array}$ & $\begin{array}{c}0.029 \\
(0.810)\end{array}$ & $\begin{array}{c}0.022 \\
(0.537)\end{array}$ \\
\hline rho & 0.372 & & 0.344 & & 0.372 & & 0.344 & \\
\hline
\end{tabular}

Notes: T-statistics are in parentheses. As with McMillen (1992), the standard errors used to calculate the t-statistics in the estimations with spatially-dependent errors are conditional on $\rho$ and so that the t-statistics overestimate the unconditional t-statistics.

Table 15: SDE Probit Estimates - Kansas City 


\begin{tabular}{|c|c|c|c|c|c|c|c|c|}
\hline & $\overline{\overline{\mathrm{I}}}$ & $\overline{\overline{\text { II }}}$ & $\overline{\overline{I I I}}$ & $\overline{\mathrm{IV}}$ & $\overline{\mathrm{II}}$ & II & $\overline{\text { III }}$ & $\overline{\overline{I V}}$ \\
\hline Spatial Errors & $\bar{Y}$ & $\mathrm{~N}$ & $\bar{Y}$ & $\mathrm{~N}$ & $\mathrm{Y}$ & $\mathrm{N}$ & $\mathrm{Y}$ & $\mathrm{N}$ \\
\hline Tract FE & $\mathrm{N}$ & $\mathrm{N}$ & $\mathrm{Y}$ & $\mathrm{Y}$ & $\mathrm{N}$ & $\mathrm{N}$ & Y & Y \\
\hline Bank FE & $\mathrm{Y}$ & $\mathrm{Y}$ & $\mathrm{Y}$ & Y & Y & $\mathrm{Y}$ & $\mathrm{Y}$ & Y \\
\hline Constant & $\begin{array}{c}0.459 \\
(2.605)\end{array}$ & $\begin{array}{c}-0.026 \\
(-0.268)\end{array}$ & $\begin{array}{c}0.871 \\
(3.319)\end{array}$ & $\begin{array}{c}0.421 \\
(2.134)\end{array}$ & $\begin{array}{c}0.557 \\
(2.962)\end{array}$ & $\begin{array}{c}0.053 \\
(0.546)\end{array}$ & $\begin{array}{c}0.935 \\
(3.519)\end{array}$ & $\begin{array}{c}0.468 \\
(2.371)\end{array}$ \\
\hline D1998 & $\begin{array}{c}-0.112 \\
(-1.500)\end{array}$ & $\begin{array}{c}-0.093 \\
(-2.007)\end{array}$ & $\begin{array}{c}-0.025 \\
(-0.356)\end{array}$ & $\begin{array}{c}0.001 \\
(0.014)\end{array}$ & $\begin{array}{c}-0.127 \\
(-1.716)\end{array}$ & $\begin{array}{c}-0.110 \\
(-2.362)\end{array}$ & $\begin{array}{c}-0.037 \\
(-0.532)\end{array}$ & $\begin{array}{c}-0.013 \\
(-0.256)\end{array}$ \\
\hline D1999 & $\begin{array}{c}-0.092 \\
(-1.220)\end{array}$ & $\begin{array}{c}-0.074 \\
(-1.545)\end{array}$ & $\begin{array}{c}0.045 \\
(0.606)\end{array}$ & $\begin{array}{c}0.056 \\
(1.014)\end{array}$ & $\begin{array}{c}-0.090 \\
(-1.205)\end{array}$ & $\begin{array}{c}-0.076 \\
(-1.586)\end{array}$ & $\begin{array}{c}0.054 \\
(0.727)\end{array}$ & $\begin{array}{c}0.063 \\
(1.123)\end{array}$ \\
\hline D2000 & $\begin{array}{c}-0.075 \\
(-0.900)\end{array}$ & $\begin{array}{c}-0.043 \\
(-0.872)\end{array}$ & $\begin{array}{c}0.156 \\
(1.840)\end{array}$ & $\begin{array}{c}0.169 \\
(2.759)\end{array}$ & $\begin{array}{c}-0.037 \\
(-0.445)\end{array}$ & $\begin{array}{c}-0.010 \\
(-0.203)\end{array}$ & $\begin{array}{c}0.203 \\
(2.355)\end{array}$ & $\begin{array}{c}0.213 \\
(3.448)\end{array}$ \\
\hline D2001 & $\begin{array}{c}0.086 \\
(1.011)\end{array}$ & $\begin{array}{c}0.133 \\
(2.629)\end{array}$ & $\begin{array}{c}0.387 \\
(4.300)\end{array}$ & $\begin{array}{c}0.405 \\
(6.158)\end{array}$ & $\begin{array}{c}0.148 \\
(1.714)\end{array}$ & $\begin{array}{c}0.193 \\
(3.738)\end{array}$ & $\begin{array}{c}0.462 \\
(4.953)\end{array}$ & $\begin{array}{c}0.480 \\
(7.149)\end{array}$ \\
\hline LnD & $\begin{array}{c}-0.868 \\
(-12.382)\end{array}$ & $\begin{array}{c}-0.852 \\
(-14.625)\end{array}$ & $\begin{array}{c}-1.128 \\
(-16.509)\end{array}$ & $\begin{array}{c}-1.132 \\
(-17.838)\end{array}$ & $\begin{array}{c}-0.590 \\
(-5.402)\end{array}$ & $\begin{array}{c}-0.605 \\
(-7.725)\end{array}$ & $\begin{array}{c}-0.848 \\
(-8.042)\end{array}$ & $\begin{array}{c}-0.882 \\
(-10.643)\end{array}$ \\
\hline LnD*M & $\begin{array}{c}0.450 \\
(5.697)\end{array}$ & $\begin{array}{c}0.404 \\
(6.161)\end{array}$ & $\begin{array}{c}0.280 \\
(3.674)\end{array}$ & $\begin{array}{c}0.240 \\
(3.438)\end{array}$ & $\begin{array}{c}0.355 \\
(2.734)\end{array}$ & $\begin{array}{c}0.321 \\
(3.440)\end{array}$ & $\begin{array}{c}0.158 \\
(1.266)\end{array}$ & $\begin{array}{c}0.137 \\
(1.401)\end{array}$ \\
\hline $\mathrm{LnD}^{*} \mathrm{~L}$ & $\begin{array}{c}0.782 \\
(11.914)\end{array}$ & $\begin{array}{c}0.724 \\
(12.889)\end{array}$ & $\begin{array}{c}0.587 \\
(9.011)\end{array}$ & $\begin{array}{c}0.535 \\
(8.850)\end{array}$ & $\begin{array}{c}0.384 \\
(3.189)\end{array}$ & $\begin{array}{c}0.360 \\
(4.219)\end{array}$ & $\begin{array}{c}0.188 \\
(1.602)\end{array}$ & $\begin{array}{c}0.168 \\
(1.875)\end{array}$ \\
\hline $\mathrm{LnD}^{*} \mathrm{~T}$ & $\begin{array}{c}-0.063 \\
(-4.310)\end{array}$ & $\begin{array}{c}-0.075 \\
(-7.182)\end{array}$ & $\begin{array}{l}-0.042 \\
(-2.941)\end{array}$ & $\begin{array}{c}-0.052 \\
(-4.501)\end{array}$ & & & & \\
\hline $\operatorname{LnD}^{*} \mathrm{~T}^{*} \mathrm{~S}$ & & & & & $\begin{array}{c}-0.188 \\
(-5.295)\end{array}$ & $\begin{array}{c}-0.186 \\
(-7.042)\end{array}$ & $\begin{array}{c}-0.168 \\
(-4.937)\end{array}$ & $\begin{array}{c}-0.165 \\
(-6.010)\end{array}$ \\
\hline $\mathrm{LnD}^{*} \mathrm{~T}^{*} \mathrm{M}$ & & & & & $\begin{array}{c}-0.187 \\
(-5.735)\end{array}$ & $\begin{array}{c}-0.184 \\
(-7.282)\end{array}$ & $\begin{array}{c}-0.150 \\
(-4.661)\end{array}$ & $\begin{array}{l}-0.150 \\
(-5.697)\end{array}$ \\
\hline $\mathrm{LnD}^{*} \mathrm{~T}^{*} \mathrm{~L}$ & & & & & $\begin{array}{c}-0.007 \\
(-0.384)\end{array}$ & $\begin{array}{c}-0.020 \\
(-1.513)\end{array}$ & $\begin{array}{c}0.014 \\
(0.783)\end{array}$ & $\begin{array}{c}0.004 \\
(0.311)\end{array}$ \\
\hline LnFirms & $\begin{array}{c}0.481 \\
(24.908)\end{array}$ & $\begin{array}{c}0.491 \\
(30.814)\end{array}$ & $\begin{array}{c}0.025 \\
(0.329)\end{array}$ & $\begin{array}{c}0.049 \\
(0.811)\end{array}$ & $\begin{array}{c}0.480 \\
(24.898)\end{array}$ & $\begin{array}{c}0.491 \\
(30.774)\end{array}$ & $\begin{array}{c}-0.000 \\
(-0.001)\end{array}$ & $\begin{array}{c}0.022 \\
(0.352)\end{array}$ \\
\hline rho & 0.422 & & 0.338 & & 0.408 & & 0.328 & \\
\hline
\end{tabular}

Notes: T-statistics are in parentheses. As with McMillen (1992), the standard errors used to calculate the t-statistics in the estimations with spatially-dependent errors are conditional on $\rho$ and so that the t-statistics overestimate the unconditional t-statistics.

Table 16: SDE Probit Estimates - Nashville 


\begin{tabular}{|c|c|c|c|c|c|c|c|c|}
\hline & $\overline{\mathrm{I}}$ & $\overline{\mathrm{II}}$ & $\overline{\text { III }}$ & $\overline{\mathrm{IV}}$ & 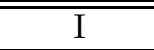 & $\overline{\mathrm{II}}$ & III & IV \\
\hline $\begin{array}{l}\text { Spatial Er- } \\
\text { rors }\end{array}$ & $\bar{Y}$ & $\mathrm{~N}$ & $\bar{Y}$ & $\mathrm{~N}$ & $\bar{Y}$ & $\mathrm{~N}$ & $\bar{Y}$ & $\mathrm{~N}$ \\
\hline Tract FE & $\mathrm{N}$ & $\mathrm{N}$ & Y & Y & $\mathrm{N}$ & $\mathrm{N}$ & Y & $\mathrm{Y}$ \\
\hline Bank FE & $\mathrm{Y}$ & $\mathrm{Y}$ & Y & Y & Y & Y & Y & Y \\
\hline Constant & $\begin{array}{c}-0.703 \\
(-13.187)\end{array}$ & $\begin{array}{c}-1.015 \\
(-19.236)\end{array}$ & $\begin{array}{c}0.283 \\
(1.444)\end{array}$ & $\begin{array}{c}-0.122 \\
(-0.626)\end{array}$ & $\begin{array}{c}-0.698 \\
(-12.904)\end{array}$ & $\begin{array}{c}-1.005 \\
(-18.957)\end{array}$ & $\begin{array}{c}0.281 \\
(1.430)\end{array}$ & $\begin{array}{c}-0.117 \\
(-0.598)\end{array}$ \\
\hline D1998 & $\begin{array}{c}-0.069 \\
(-1.883)\end{array}$ & $\begin{array}{c}-0.050 \\
(-1.311)\end{array}$ & $\begin{array}{c}-0.103 \\
(-2.877)\end{array}$ & $\begin{array}{c}-0.077 \\
(-1.902)\end{array}$ & $\begin{array}{c}-0.072 \\
(-1.961)\end{array}$ & $\begin{array}{c}-0.054 \\
(-1.431)\end{array}$ & $\begin{array}{c}-0.107 \\
(-2.980)\end{array}$ & $\begin{array}{c}-0.083 \\
(-2.046)\end{array}$ \\
\hline D1999 & $\begin{array}{c}-0.038 \\
(-1.037)\end{array}$ & $\begin{array}{l}-0.025 \\
(-0.651)\end{array}$ & $\begin{array}{l}-0.015 \\
(-0.411)\end{array}$ & $\begin{array}{c}0.001 \\
(0.018)\end{array}$ & $\begin{array}{c}-0.044 \\
(-1.156)\end{array}$ & $\begin{array}{l}-0.035 \\
(-0.902)\end{array}$ & $\begin{array}{c}-0.022 \\
(-0.592)\end{array}$ & $\begin{array}{c}-0.011 \\
(-0.262)\end{array}$ \\
\hline D2000 & $\begin{array}{c}-0.164 \\
(-4.309)\end{array}$ & $\begin{array}{c}-0.148 \\
(-3.766)\end{array}$ & $\begin{array}{c}-0.078 \\
(-1.904)\end{array}$ & $\begin{array}{c}-0.063 \\
(-1.312)\end{array}$ & $\begin{array}{c}-0.168 \\
(-4.189)\end{array}$ & $\begin{array}{c}-0.158 \\
(-3.989)\end{array}$ & $\begin{array}{c}-0.084 \\
(-1.985)\end{array}$ & $\begin{array}{c}-0.076 \\
(-1.558)\end{array}$ \\
\hline D2001 & $\begin{array}{c}0.081 \\
(2.097)\end{array}$ & $\begin{array}{c}0.081 \\
(2.086)\end{array}$ & $\begin{array}{c}0.251 \\
(5.671)\end{array}$ & $\begin{array}{c}0.247 \\
(4.721)\end{array}$ & $\begin{array}{c}0.078 \\
(1.831)\end{array}$ & $\begin{array}{c}0.069 \\
(1.751)\end{array}$ & $\begin{array}{c}0.246 \\
(5.273)\end{array}$ & $\begin{array}{c}0.232 \\
(4.386)\end{array}$ \\
\hline LnD & $\begin{array}{c}-0.820 \\
(-22.027)\end{array}$ & $\begin{array}{c}-0.718 \\
(-20.845)\end{array}$ & $\begin{array}{c}-1.089 \\
(-29.110)\end{array}$ & $\begin{array}{c}-0.965 \\
(-25.301)\end{array}$ & $\begin{array}{c}-0.754 \\
(-13.053)\end{array}$ & $\begin{array}{c}-0.651 \\
(-12.087)\end{array}$ & $\begin{array}{c}-1.044 \\
(-18.391)\end{array}$ & $\begin{array}{c}-0.920 \\
(-15.981)\end{array}$ \\
\hline $\operatorname{LnD}^{*} \mathrm{M}$ & $\begin{array}{c}-0.139 \\
(-3.657)\end{array}$ & $\begin{array}{c}-0.122 \\
(-3.552)\end{array}$ & $\begin{array}{c}-0.061 \\
(-1.642)\end{array}$ & $\begin{array}{c}-0.053 \\
(-1.439)\end{array}$ & $\begin{array}{c}-0.244 \\
(-3.746)\end{array}$ & $\begin{array}{c}-0.240 \\
(-3.874)\end{array}$ & $\begin{array}{c}-0.135 \\
(-2.120)\end{array}$ & $\begin{array}{c}-0.142 \\
(-2.180)\end{array}$ \\
\hline LnD*L & $\begin{array}{c}0.352 \\
(8.116)\end{array}$ & $\begin{array}{c}0.180 \\
(4.895)\end{array}$ & $\begin{array}{c}0.230 \\
(5.533)\end{array}$ & $\begin{array}{c}0.097 \\
(2.402)\end{array}$ & $\begin{array}{c}0.304 \\
(4.272)\end{array}$ & $\begin{array}{c}0.152 \\
(2.393)\end{array}$ & $\begin{array}{c}0.201 \\
(2.925)\end{array}$ & $\begin{array}{c}0.090 \\
(1.338)\end{array}$ \\
\hline $\mathrm{LnD}^{*} \mathrm{~T}$ & $\begin{array}{c}-0.036 \\
(-4.309)\end{array}$ & $\begin{array}{c}-0.043 \\
(-5.108)\end{array}$ & $\begin{array}{c}-0.039 \\
(-4.712)\end{array}$ & $\begin{array}{c}-0.046 \\
(-5.235)\end{array}$ & & & & \\
\hline $\operatorname{LnD}{ }^{*} \mathrm{~T}^{*} \mathrm{~S}$ & & & & & $\begin{array}{c}-0.065 \\
(-3.049)\end{array}$ & $\begin{array}{c}-0.072 \\
(-3.546)\end{array}$ & $\begin{array}{c}-0.058 \\
(-2.840)\end{array}$ & $\begin{array}{c}-0.065 \\
(-3.124)\end{array}$ \\
\hline $\mathrm{LnD}^{*} \mathrm{~T}^{*} \mathrm{M}$ & & & & & $\begin{array}{c}-0.018 \\
(-1.366)\end{array}$ & $\begin{array}{c}-0.018 \\
(-1.509)\end{array}$ & $\begin{array}{c}-0.025 \\
(-1.987)\end{array}$ & $\begin{array}{c}-0.025 \\
(-2.046)\end{array}$ \\
\hline $\mathrm{LnD}^{*} \mathrm{~T}^{*} \mathrm{~L}$ & & & & & $\begin{array}{c}-0.046 \\
(-3.311)\end{array}$ & $\begin{array}{c}-0.062 \\
(-4.630)\end{array}$ & $\begin{array}{c}-0.048 \\
(-3.495)\end{array}$ & $\begin{array}{c}-0.065 \\
(-4.610)\end{array}$ \\
\hline LnFirms & $\begin{array}{c}0.491 \\
(42.517)\end{array}$ & $\begin{array}{c}0.449 \\
(34.726)\end{array}$ & $\begin{array}{c}0.077 \\
(1.379)\end{array}$ & $\begin{array}{c}0.075 \\
(1.167)\end{array}$ & $\begin{array}{c}0.491 \\
(42.520)\end{array}$ & $\begin{array}{c}0.450 \\
(34.728)\end{array}$ & $\begin{array}{c}0.081 \\
(1.454)\end{array}$ & $\begin{array}{c}0.080 \\
(1.231)\end{array}$ \\
\hline rho & 0.415 & & 0.302 & & 0.413 & & 0.300 & \\
\hline
\end{tabular}

Notes: T-statistics are in parentheses. As with McMillen (1992), the standard errors used to calculate the t-statistics in the estimations with spatially-dependent errors are conditional on $\rho$ and so that the t-statistics overestimate the unconditional t-statistics.

Table 17: SDE Probit Estimates - Providence 


\begin{tabular}{|c|c|c|c|c|c|c|c|c|}
\hline & $\overline{\mathrm{I}}$ & $\overline{\mathrm{II}}$ & $\overline{\text { III }}$ & $\overline{\mathrm{IV}}$ & $\overline{\bar{I}}$ & $\overline{\mathrm{III}}$ & $\overline{\text { IIII }}$ & 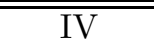 \\
\hline $\begin{array}{l}\text { Spatial Er- } \\
\text { rors }\end{array}$ & $\bar{Y}$ & $\mathrm{~N}$ & $\bar{Y}$ & $\mathrm{~N}$ & $\bar{Y}$ & $\mathrm{~N}$ & $\bar{Y}$ & $\overline{\mathrm{N}}$ \\
\hline Tract FE & $\mathrm{N}$ & $\mathrm{N}$ & Y & Y & $\mathrm{N}$ & $\mathrm{N}$ & Y & Y \\
\hline Bank FE & $\mathrm{Y}$ & $\mathrm{Y}$ & $\mathrm{Y}$ & Y & Y & Y & Y & Y \\
\hline Constant & $\begin{array}{c}0.093 \\
(0.935)\end{array}$ & $\begin{array}{l}-0.029 \\
(-0.275)\end{array}$ & $\begin{array}{c}0.559 \\
(2.552)\end{array}$ & $\begin{array}{c}0.425 \\
(2.002)\end{array}$ & $\begin{array}{c}0.080 \\
(0.779)\end{array}$ & $\begin{array}{c}-0.043 \\
(-0.401)\end{array}$ & $\begin{array}{c}0.532 \\
(2.412)\end{array}$ & $\begin{array}{c}0.399 \\
(1.876)\end{array}$ \\
\hline D1998 & $\begin{array}{c}-0.156 \\
(-3.104)\end{array}$ & $\begin{array}{c}-0.152 \\
(-3.950)\end{array}$ & $\begin{array}{c}0.110 \\
(1.975)\end{array}$ & $\begin{array}{c}0.100 \\
(2.115)\end{array}$ & $\begin{array}{c}-0.156 \\
(-3.030)\end{array}$ & $\begin{array}{c}-0.151 \\
(-3.867)\end{array}$ & $\begin{array}{c}0.118 \\
(2.077)\end{array}$ & $\begin{array}{c}0.108 \\
(2.238)\end{array}$ \\
\hline D1999 & $\begin{array}{l}-0.192 \\
(-3.657)\end{array}$ & $\begin{array}{c}-0.197 \\
(-4.956)\end{array}$ & $\begin{array}{c}0.199 \\
(3.175)\end{array}$ & $\begin{array}{c}0.176 \\
(3.131)\end{array}$ & $\begin{array}{c}-0.194 \\
(-3.337)\end{array}$ & $\begin{array}{c}-0.195 \\
(-4.591)\end{array}$ & $\begin{array}{c}0.214 \\
(3.149)\end{array}$ & $\begin{array}{c}0.192 \\
(3.220)\end{array}$ \\
\hline D2000 & $\begin{array}{c}-0.312 \\
(-5.873)\end{array}$ & $\begin{array}{c}-0.310 \\
(-7.343)\end{array}$ & $\begin{array}{c}0.227 \\
(3.062)\end{array}$ & $\begin{array}{c}0.205 \\
(2.976)\end{array}$ & $\begin{array}{c}-0.318 \\
(-4.840)\end{array}$ & $\begin{array}{c}-0.309 \\
(-6.358)\end{array}$ & $\begin{array}{c}0.247 \\
(2.927)\end{array}$ & $\begin{array}{c}0.227 \\
(3.011)\end{array}$ \\
\hline D2001 & $\begin{array}{c}-0.259 \\
(-4.879)\end{array}$ & $\begin{array}{c}-0.266 \\
(-6.307)\end{array}$ & $\begin{array}{c}0.316 \\
(4.142)\end{array}$ & $\begin{array}{c}0.284 \\
(3.969)\end{array}$ & $\begin{array}{c}-0.271 \\
(-3.709)\end{array}$ & $\begin{array}{c}-0.268 \\
(-5.061)\end{array}$ & $\begin{array}{c}0.337 \\
(3.660)\end{array}$ & $\begin{array}{c}0.309 \\
(3.787)\end{array}$ \\
\hline LnD & $\begin{array}{c}-1.535 \\
(-24.878)\end{array}$ & $\begin{array}{c}-1.551 \\
(-23.403)\end{array}$ & $\begin{array}{c}-1.673 \\
(-26.098)\end{array}$ & $\begin{array}{c}-1.685 \\
(-24.390)\end{array}$ & $\begin{array}{c}-1.626 \\
(-19.981)\end{array}$ & $\begin{array}{c}-1.607 \\
(-18.223)\end{array}$ & $\begin{array}{c}-1.752 \\
(-20.905)\end{array}$ & $\begin{array}{c}-1.733 \\
(-18.983)\end{array}$ \\
\hline $\operatorname{LnD}^{*} \mathrm{M}$ & $\begin{array}{c}0.521 \\
(6.962)\end{array}$ & $\begin{array}{c}0.633 \\
(8.030)\end{array}$ & $\begin{array}{c}0.450 \\
(5.726)\end{array}$ & $\begin{array}{c}0.563 \\
(6.898)\end{array}$ & $\begin{array}{c}0.644 \\
(6.810)\end{array}$ & $\begin{array}{c}0.714 \\
(7.070)\end{array}$ & $\begin{array}{c}0.586 \\
(5.981)\end{array}$ & $\begin{array}{c}0.657 \\
(6.299)\end{array}$ \\
\hline LnD*L & $\begin{array}{c}1.032 \\
(16.031)\end{array}$ & $\begin{array}{c}0.979 \\
(14.619)\end{array}$ & $\begin{array}{c}0.815 \\
(11.799)\end{array}$ & $\begin{array}{c}0.771 \\
(10.835)\end{array}$ & $\begin{array}{c}1.127 \\
(11.161)\end{array}$ & $\begin{array}{c}1.032 \\
(10.421)\end{array}$ & $\begin{array}{c}0.880 \\
(8.475)\end{array}$ & $\begin{array}{c}0.802 \\
(7.768)\end{array}$ \\
\hline $\mathrm{LnD}^{*} \mathrm{~T}$ & $\begin{array}{c}-0.013 \\
(-1.239)\end{array}$ & $\begin{array}{c}-0.017 \\
(-1.861)\end{array}$ & $\begin{array}{c}-0.001 \\
(-0.078)\end{array}$ & $\begin{array}{c}-0.004 \\
(-0.367)\end{array}$ & & & & \\
\hline $\mathrm{LnD}^{*} \mathrm{~T}^{*} \mathrm{~S}$ & & & & & $\begin{array}{c}0.030 \\
(1.138)\end{array}$ & $\begin{array}{c}0.010 \\
(0.336)\end{array}$ & $\begin{array}{c}0.037 \\
(1.365)\end{array}$ & $\begin{array}{c}0.020 \\
(0.671)\end{array}$ \\
\hline $\mathrm{LnD}^{*} \mathrm{~T}^{*} \mathrm{M}$ & & & & & $\begin{array}{c}-0.033 \\
(-1.314)\end{array}$ & $\begin{array}{c}-0.034 \\
(-1.701)\end{array}$ & $\begin{array}{c}-0.038 \\
(-1.528)\end{array}$ & $\begin{array}{c}-0.034 \\
(-1.634)\end{array}$ \\
\hline $\operatorname{LnD}^{*} \mathrm{~T}^{*} \mathrm{~L}$ & & & & & $\begin{array}{c}-0.015 \\
(-0.858)\end{array}$ & $\begin{array}{c}-0.016 \\
(-1.173)\end{array}$ & $\begin{array}{c}0.007 \\
(0.385)\end{array}$ & $\begin{array}{c}0.005 \\
(0.341)\end{array}$ \\
\hline LnFirms & $\begin{array}{c}0.767 \\
(46.695)\end{array}$ & $\begin{array}{c}0.747 \\
(43.959)\end{array}$ & $\begin{array}{c}-0.072 \\
(-0.823)\end{array}$ & $\begin{array}{c}-0.057 \\
(-0.655)\end{array}$ & $\begin{array}{c}0.766 \\
(46.671)\end{array}$ & $\begin{array}{c}0.746 \\
(43.925)\end{array}$ & $\begin{array}{c}-0.081 \\
(-0.925)\end{array}$ & $\begin{array}{c}-0.066 \\
(-0.759)\end{array}$ \\
\hline rho & 0.434 & & 0.430 & & 0.433 & & 0.428 & \\
\hline
\end{tabular}

Notes: T-statistics are in parentheses. As with McMillen (1992), the standard errors used to calculate the t-statistics in the estimations with spatially-dependent errors are conditional on $\rho$ and so that the t-statistics overestimate the unconditional t-statistics.

Table 18: SDE Probit Estimates - Rochester 


\begin{tabular}{|c|c|c|c|c|c|c|c|c|}
\hline & $\overline{\bar{I}}$ & $\overline{\overline{I I I}}$ & $\overline{\text { III }}$ & $\overline{\mathrm{IV}}$ & $\overline{\mathrm{I}}$ & $\overline{\mathrm{II}}$ & III & $\overline{\mathrm{IV}}$ \\
\hline $\begin{array}{ll}\begin{array}{l}\text { Spatial Er- } \\
\text { rors }\end{array} & \end{array}$ & $\bar{Y}$ & $\mathrm{~N}$ & $\bar{Y}$ & $\bar{N}$ & $\bar{Y}$ & $\mathrm{~N}$ & $\bar{Y}$ & $\mathrm{~N}$ \\
\hline Tract FE & $\mathrm{N}$ & $\mathrm{N}$ & Y & Y & $\mathrm{N}$ & $\mathrm{N}$ & Y & Y \\
\hline Bank FE & Y & Y & $\mathrm{Y}$ & $\mathrm{Y}$ & Y & Y & Y & Y \\
\hline Constant & $\begin{array}{c}0.346 \\
(3.213)\end{array}$ & $\begin{array}{c}-0.158 \\
(-2.909)\end{array}$ & $\begin{array}{c}1.147 \\
(4.524)\end{array}$ & $\begin{array}{c}0.814 \\
(3.375)\end{array}$ & $\begin{array}{c}0.357 \\
(3.295)\end{array}$ & $\begin{array}{c}-0.146 \\
(-2.700)\end{array}$ & $\begin{array}{c}1.140 \\
(4.498)\end{array}$ & $\begin{array}{c}0.808 \\
(3.349)\end{array}$ \\
\hline D1998 & $\begin{array}{c}-0.123 \\
(-2.429)\end{array}$ & $\begin{array}{c}-0.114 \\
(-3.337)\end{array}$ & $\begin{array}{c}-0.026 \\
(-0.533)\end{array}$ & $\begin{array}{c}-0.023 \\
(-0.646)\end{array}$ & $\begin{array}{c}-0.124 \\
(-2.451)\end{array}$ & $\begin{array}{c}-0.115 \\
(-3.377)\end{array}$ & $\begin{array}{c}-0.028 \\
(-0.573)\end{array}$ & $\begin{array}{c}-0.026 \\
(-0.720)\end{array}$ \\
\hline D1999 & $\begin{array}{c}-0.442 \\
(-8.486)\end{array}$ & $\begin{array}{c}-0.410 \\
(-11.605)\end{array}$ & $\begin{array}{c}-0.236 \\
(-4.487)\end{array}$ & $\begin{array}{c}-0.214 \\
(-5.224)\end{array}$ & $\begin{array}{c}-0.449 \\
(-8.619)\end{array}$ & $\begin{array}{c}-0.417 \\
(-11.787)\end{array}$ & $\begin{array}{c}-0.243 \\
(-4.603)\end{array}$ & $\begin{array}{c}-0.221 \\
(-5.395)\end{array}$ \\
\hline D2000 & $\begin{array}{c}-0.413 \\
(-7.568)\end{array}$ & $\begin{array}{c}-0.388 \\
(-9.915)\end{array}$ & $\begin{array}{c}-0.051 \\
(-0.846)\end{array}$ & $\begin{array}{c}-0.041 \\
(-0.819)\end{array}$ & $\begin{array}{c}-0.422 \\
(-7.664)\end{array}$ & $\begin{array}{c}-0.397 \\
(-10.109)\end{array}$ & $\begin{array}{c}-0.060 \\
(-0.983)\end{array}$ & $\begin{array}{c}-0.050 \\
(-1.000)\end{array}$ \\
\hline D2001 & $\begin{array}{c}-0.398 \\
(-6.957)\end{array}$ & $\begin{array}{c}-0.370 \\
(-8.933)\end{array}$ & $\begin{array}{c}0.060 \\
(0.917)\end{array}$ & $\begin{array}{c}0.068 \\
(1.214)\end{array}$ & $\begin{array}{c}-0.408 \\
(-6.981)\end{array}$ & $\begin{array}{c}-0.382 \\
(-9.151)\end{array}$ & $\begin{array}{c}0.050 \\
(0.744)\end{array}$ & $\begin{array}{c}0.057 \\
(1.008)\end{array}$ \\
\hline LnD & $\begin{array}{c}-0.598 \\
(-10.864)\end{array}$ & $\begin{array}{c}-0.574 \\
(-12.169)\end{array}$ & $\begin{array}{c}-0.836 \\
(-14.876)\end{array}$ & $\begin{array}{c}-0.811 \\
(-15.812)\end{array}$ & $\begin{array}{c}-0.678 \\
(-8.562)\end{array}$ & $\begin{array}{c}-0.637 \\
(-8.632)\end{array}$ & $\begin{array}{c}-0.875 \\
(-10.812)\end{array}$ & $\begin{array}{c}-0.835 \\
(-10.676)\end{array}$ \\
\hline $\mathrm{LnD}^{*} \mathrm{M}$ & $\begin{array}{c}0.250 \\
(4.314)\end{array}$ & $\begin{array}{c}0.231 \\
(4.744)\end{array}$ & $\begin{array}{c}0.181 \\
(3.203)\end{array}$ & $\begin{array}{c}0.166 \\
(3.313)\end{array}$ & $\begin{array}{c}0.275 \\
(3.014)\end{array}$ & $\begin{array}{c}0.232 \\
(2.817)\end{array}$ & $\begin{array}{c}0.178 \\
(1.961)\end{array}$ & $\begin{array}{c}0.138 \\
(1.612)\end{array}$ \\
\hline $\mathrm{LnD}^{*} \mathrm{~L}$ & $\begin{array}{c}0.418 \\
(7.582)\end{array}$ & $\begin{array}{c}0.341 \\
(7.260)\end{array}$ & $\begin{array}{c}0.273 \\
(4.972)\end{array}$ & $\begin{array}{c}0.208 \\
(4.279)\end{array}$ & $\begin{array}{c}0.547 \\
(6.186)\end{array}$ & $\begin{array}{c}0.459 \\
(5.771)\end{array}$ & $\begin{array}{c}0.347 \\
(3.895)\end{array}$ & $\begin{array}{c}0.274 \\
(3.298)\end{array}$ \\
\hline $\mathrm{LnD}^{*} \mathrm{~T}$ & $\begin{array}{c}-0.026 \\
(-2.538)\end{array}$ & $\begin{array}{c}-0.019 \\
(-2.133)\end{array}$ & $\begin{array}{c}0.016 \\
(1.516)\end{array}$ & $\begin{array}{c}0.022 \\
(2.325)\end{array}$ & & & & \\
\hline $\operatorname{LnD} * \mathrm{~T}^{*} \mathrm{~S}$ & & & & & $\begin{array}{c}0.011 \\
(0.391)\end{array}$ & $\begin{array}{c}0.011 \\
(0.398)\end{array}$ & $\begin{array}{c}0.033 \\
(1.196)\end{array}$ & $\begin{array}{c}0.033 \\
(1.156)\end{array}$ \\
\hline $\mathrm{LnD}^{*} \mathrm{~T}^{*} \mathrm{M}$ & & & & & $\begin{array}{c}0.0001 \\
(0.007)\end{array}$ & $\begin{array}{c}0.011 \\
(0.788)\end{array}$ & $\begin{array}{c}0.035 \\
(2.127)\end{array}$ & $\begin{array}{c}0.046 \\
(3.191)\end{array}$ \\
\hline $\operatorname{LnD}^{*} \mathrm{~T}^{*} \mathrm{~L}$ & & & & & $\begin{array}{c}-0.052 \\
(-3.479)\end{array}$ & $\begin{array}{c}-0.047 \\
(-3.913)\end{array}$ & $\begin{array}{c}-0.002 \\
(-0.163)\end{array}$ & $\begin{array}{c}0.001 \\
(0.074)\end{array}$ \\
\hline LnFirms & $\begin{array}{c}0.609 \\
(46.482)\end{array}$ & $\begin{array}{c}0.584 \\
(44.833)\end{array}$ & $\begin{array}{c}-0.006 \\
(-0.126)\end{array}$ & $\begin{array}{c}-0.018 \\
(-0.363)\end{array}$ & $\begin{array}{c}0.610 \\
(46.521)\end{array}$ & $\begin{array}{c}0.585 \\
(44.878)\end{array}$ & $\begin{array}{c}-0.001 \\
(-0.025)\end{array}$ & $\begin{array}{c}-0.013 \\
(-0.265)\end{array}$ \\
\hline rho & 0.311 & & 0.313 & & 0.310 & & 0.312 & \\
\hline
\end{tabular}

Notes: T-statistics are in parentheses. As with McMillen (1992), the standard errors used to calculate the t-statistics in the estimations with spatially-dependent errors are conditional on $\rho$ and so that the t-statistics overestimate the unconditional t-statistics.

Table 19: SDE Probit Estimates - San Antonio 


\begin{tabular}{|c|c|c|c|c|c|c|c|c|}
\hline & $\overline{\overline{\mathrm{I}}}$ & $\overline{\overline{\text { II }}}$ & $\overline{\overline{\text { III }}}$ & $\overline{\mathrm{IV}}$ & I & $\overline{\overline{\text { II }}}$ & III & $\overline{\overline{I V}}$ \\
\hline $\begin{array}{l}\text { Spatial Er- } \\
\text { rors }\end{array}$ & $\bar{Y}$ & $\mathrm{~N}$ & $\bar{Y}$ & $\mathrm{~N}$ & $\bar{Y}$ & $\mathrm{~N}$ & $\bar{Y}$ & $\mathrm{~N}$ \\
\hline Tract FE & $\mathrm{N}$ & $\mathrm{N}$ & Y & Y & $\mathrm{N}$ & $\mathrm{N}$ & Y & Y \\
\hline Bank FE & Y & Y & Y & Y & Y & Y & Y & Y \\
\hline Constant & $\begin{array}{c}-3.006 \\
(-24.125)\end{array}$ & $\begin{array}{l}-2.996 \\
(-7.617)\end{array}$ & $\begin{array}{c}-3.037 \\
(-14.028)\end{array}$ & $\begin{array}{l}-3.042 \\
(-6.049)\end{array}$ & $\begin{array}{c}-3.027 \\
(-23.605)\end{array}$ & $\begin{array}{c}-3.015 \\
(-7.454)\end{array}$ & $\begin{array}{c}-3.072 \\
(-13.815)\end{array}$ & $\begin{array}{c}-3.075 \\
(-5.919)\end{array}$ \\
\hline D1998 & $\begin{array}{c}-0.123 \\
(-4.730)\end{array}$ & $\begin{array}{c}-0.115 \\
(-4.464)\end{array}$ & $\begin{array}{c}0.034 \\
(1.224)\end{array}$ & $\begin{array}{c}0.030 \\
(1.016)\end{array}$ & $\begin{array}{l}-0.116 \\
(-4.415)\end{array}$ & $\begin{array}{c}-0.109 \\
(-4.226)\end{array}$ & $\begin{array}{c}0.039 \\
(1.381)\end{array}$ & $\begin{array}{c}0.032 \\
(1.090)\end{array}$ \\
\hline D1999 & $\begin{array}{c}-0.071 \\
(-2.722)\end{array}$ & $\begin{array}{c}-0.072 \\
(-2.767)\end{array}$ & $\begin{array}{c}0.230 \\
(7.107)\end{array}$ & $\begin{array}{c}0.205 \\
(5.860)\end{array}$ & $\begin{array}{c}-0.070 \\
(-2.603)\end{array}$ & $\begin{array}{c}-0.073 \\
(-2.779)\end{array}$ & $\begin{array}{c}0.228 \\
(6.838)\end{array}$ & $\begin{array}{c}0.199 \\
(5.584)\end{array}$ \\
\hline D2000 & $\begin{array}{c}-0.174 \\
(-6.692)\end{array}$ & $\begin{array}{l}-0.168 \\
(-6.197)\end{array}$ & $\begin{array}{c}0.164 \\
(4.746)\end{array}$ & $\begin{array}{c}0.144 \\
(3.701)\end{array}$ & $\begin{array}{c}-0.170 \\
(-6.044)\end{array}$ & $\begin{array}{c}-0.167 \\
(-5.992)\end{array}$ & $\begin{array}{c}0.165 \\
(4.516)\end{array}$ & $\begin{array}{c}0.140 \\
(3.508)\end{array}$ \\
\hline D2001 & $\begin{array}{c}-0.218 \\
(-8.141)\end{array}$ & $\begin{array}{c}-0.216 \\
(-7.727)\end{array}$ & $\begin{array}{c}0.177 \\
(4.657)\end{array}$ & $\begin{array}{c}0.149 \\
(3.443)\end{array}$ & $\begin{array}{c}-0.231 \\
(-7.763)\end{array}$ & $\begin{array}{c}-0.229 \\
(-7.896)\end{array}$ & $\begin{array}{c}0.159 \\
(3.932)\end{array}$ & $\begin{array}{c}0.128 \\
(2.883)\end{array}$ \\
\hline LnD & $\begin{array}{c}-1.010 \\
(-43.30)\end{array}$ & $\begin{array}{c}-0.907 \\
(-37.671)\end{array}$ & $\begin{array}{c}-1.128 \\
(-46.819)\end{array}$ & $\begin{array}{c}-1.020 \\
(-40.459)\end{array}$ & $\begin{array}{c}-1.078 \\
(-32.411)\end{array}$ & $\begin{array}{c}-0.976 \\
(-25.388)\end{array}$ & $\begin{array}{c}-1.183 \\
(-34.184)\end{array}$ & $\begin{array}{c}-1.080 \\
(-27.495\end{array}$ \\
\hline $\mathrm{LnD}^{*} \mathrm{M}$ & $\begin{array}{c}0.197 \\
(7.770)\end{array}$ & $\begin{array}{c}0.168 \\
(6.827)\end{array}$ & $\begin{array}{c}0.127 \\
(4.941)\end{array}$ & $\begin{array}{c}0.098 \\
(3.783)\end{array}$ & $\begin{array}{c}0.481 \\
(10.683)\end{array}$ & $\begin{array}{l}0.443 \\
(9.127)\end{array}$ & $\begin{array}{c}0.412 \\
(8.949)\end{array}$ & $\begin{array}{c}0.375 \\
(7.532)\end{array}$ \\
\hline $\mathrm{LnD}^{*} \mathrm{~L}$ & $\begin{array}{c}0.805 \\
(30.936)\end{array}$ & $\begin{array}{c}0.643 \\
(24.768)\end{array}$ & $\begin{array}{c}0.616 \\
(22.812)\end{array}$ & $\begin{array}{c}0.467 \\
(16.372)\end{array}$ & $\begin{array}{c}0.793 \\
(18.430)\end{array}$ & $\begin{array}{c}0.629 \\
(13.608)\end{array}$ & $\begin{array}{c}0.577 \\
(12.964)\end{array}$ & $\begin{array}{c}0.432 \\
(8.932)\end{array}$ \\
\hline $\mathrm{LnD}^{*} \mathrm{~T}$ & $\begin{array}{c}-0.009 \\
(-1.567)\end{array}$ & $\begin{array}{c}-0.008 \\
(-1.290)\end{array}$ & $\begin{array}{c}0.001 \\
(0.216)\end{array}$ & $\begin{array}{c}0.001 \\
(0.111)\end{array}$ & & & & \\
\hline $\operatorname{LnD} * \mathrm{~T}^{*} \mathrm{~S}$ & & & & & $\begin{array}{c}0.018 \\
(1.646)\end{array}$ & $\begin{array}{c}0.019 \\
(1.448)\end{array}$ & $\begin{array}{c}0.023 \\
(2.011)\end{array}$ & $\begin{array}{c}0.024 \\
(1.773)\end{array}$ \\
\hline $\mathrm{LnD}^{*} \mathrm{~T}^{*} \mathrm{M}$ & & & & & $\begin{array}{c}-0.102 \\
(-9.317)\end{array}$ & $\begin{array}{c}-0.097 \\
(-9.109)\end{array}$ & $\begin{array}{c}-0.099 \\
(-9.018)\end{array}$ & $\begin{array}{c}-0.095 \\
(-8.550)\end{array}$ \\
\hline $\mathrm{LnD}^{*} \mathrm{~T}^{*} \mathrm{~L}$ & & & & & $\begin{array}{c}0.029 \\
(3.391)\end{array}$ & $\begin{array}{c}0.031 \\
(3.716)\end{array}$ & $\begin{array}{c}0.045 \\
(5.194)\end{array}$ & $\begin{array}{c}0.045 \\
(5.102)\end{array}$ \\
\hline LnFirms & $\begin{array}{c}0.528 \\
(65.759)\end{array}$ & $\begin{array}{c}0.494 \\
(54.843)\end{array}$ & $\begin{array}{c}0.049 \\
(1.470)\end{array}$ & $\begin{array}{c}0.053 \\
(1.372)\end{array}$ & $\begin{array}{c}0.530 \\
(65.887)\end{array}$ & $\begin{array}{c}0.496 \\
(54.958)\end{array}$ & $\begin{array}{c}0.064 \\
(1.922)\end{array}$ & $\begin{array}{c}0.068 \\
(1.775)\end{array}$ \\
\hline rho & 0.345 & & 0.320 & & 0.343 & & 0.318 & \\
\hline
\end{tabular}

Notes: T-statistics are in parentheses. As with McMillen (1992), the standard errors used to calculate the t-statistics in the estimations with spatially-dependent errors are conditional on $\rho$ and so that the t-statistics overestimate the unconditional t-statistics.

Table 20: SDE Probit Estimates - Seattle 